A Firm-level Productivity Diagnostic

— for Kenya's

Manufacturing And Services Sector

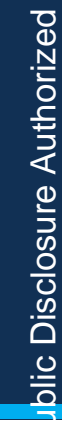





\section{A Firm-Level Productivity Diagnostic for Kenya's \\ Manufacturing and Services Sector}

Ana Cusolito and Xavier Cirera ${ }^{1}$

1 Ana Cusolito and Xavier Cirera are Senior Economists at the Innovation and Entrepreneurship Unit of the Trade \& Competitiveness Global Practice of the World Bank. 



\section{TABLE OF CONTENTS}

ABSTRACT

1. WHY IS PRODUCTIVITY SO IMPORTANT FOR KENYA'S FUTURE?

2. WHY IS A FIRM-LEVEL PRODUCTIVITY DIAGNOSTIC A USEFUL TOOL FOR POLICYMAKERS? 3

3. THE PRODUCTIVITY DIAGNOSTIC

4. IMPLICATIONS FOR POLICY

References 31

Annex

\section{LIST OF FIGURES}

Figure 1: Value added (Ksh) per worker, 1969-2010 .............................................................................. 2

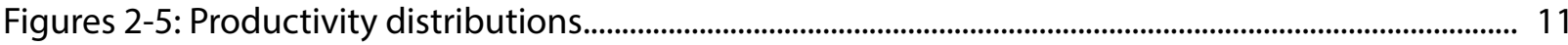

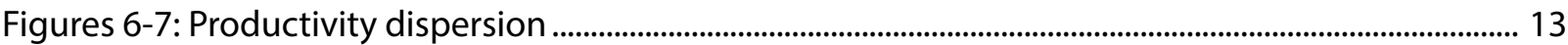

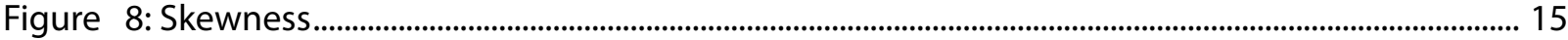

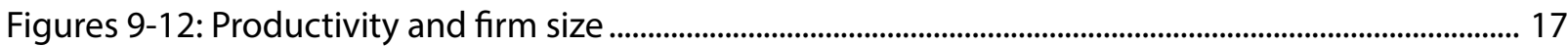

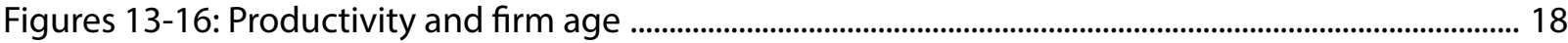

Figures 17-20: Cumulative Distribution Function (CDF) and export status ................................................. 19

Figures 21-25: Relative Cumulative Distribution Function (CDF) and firm age ........................................... 21

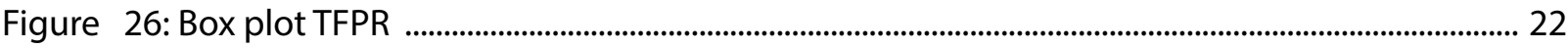

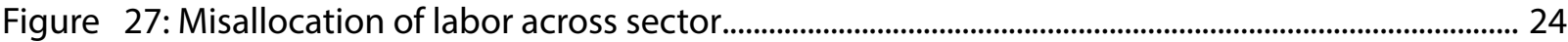

Figures 28-29: Misallocation of labor across sectors in the top 10 manufacturing and services sectors 24

Figures 30-31: OP covariance in the manufacturing and services sector 25

\section{LIST OF BOXES}

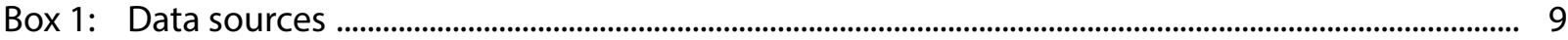

Box 2: Indirect measure of allocative efficiency ........................................................................................ 22

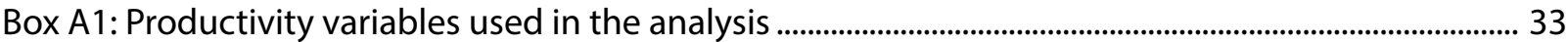

\section{LIST OF TABLES}

Table 1: Correlation between productivity measures .......................................................................................... 12

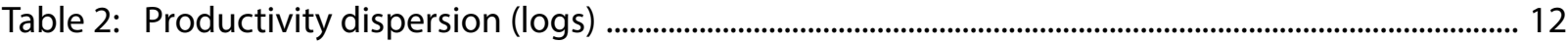

Table 3. Distance to the national productivity frontier .................................................................................. 15

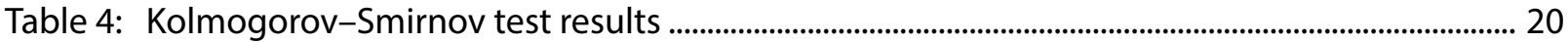

Table 8: Olley-Pakes (OP) decomposition, measuring productivity through TFPQ .................................. 25

Table 9: OP decomposition (TFPQ, manufacturing top 10 only) ................................................................... 26

Table 10: Capital and output distortion averages ........................................................................................................ 27 



\section{ABSTRACT}

$\mathrm{T}^{\mathrm{s}}$ his technical note implements a firm-level productivity diagnostic using the census of manufacturing firms and a large services survey in Kenya. By using a number of stylized productivity indicators, we aim to identify the ability of Kenyan firms to grow. The information presented in this diagnostic will help to conduct evidence-based policy-making. Specifically, implementing firm-level productivity diagnostics provide the necessary information for (i) improving the targeting of economic policies, (ii) enhancing their effectiveness, (iii) making more accurate predictions of the effects of industry shocks and policy reforms on the economy, and (iv) understanding the behavior of macroeconomic variables by tracking the evolution of variables at the firm-level. This note shows that there is a lot of heterogeneity in firms' attributes and performance, and this can potentially be attributed to the presence of economic distortions that affect the efficient allocation of resources across firms, with the manufacturing sector showing a lackluster performance compared to the services sector. Overall, the findings highlight the importance of locating productivity at the center of the competitiveness agenda as a key instrument for employment creation and poverty reduction.

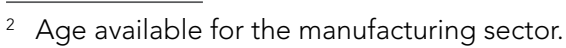





\section{WHY IS PRODUCTIVITY SO IMPORTANT FOR KENYA'S FUTURE?}

\begin{abstract}
$\Lambda$ ccelerating the process of economic Adevelopment in Kenya and achieving the ambitious targets laid out in the Vision 2030 will require a substantial increase in firm-level productivity. Kenya's economy has undergone a significant process of structural transformation over the last decade. The economy showed an accelerating trend after 2002 with GDP growth increasing steadily from below 1 percent in 2002 to 7 percent in 2007. The economy has been hit by several shocks since 2007, starting with the postelection violence in January 2008, which led to a slowdown in GDP growth to 1.5 percent and 2.7 percent in 2008 and 2009, respectively. Nevertheless, economic growth started to rebound in 2010, and recent predictions suggest higher growth rates during the period 2014-2018, exceeding the growth rates achieved before 2008 .
\end{abstract}

Amidst this positive growth context, the Kenyan Government launched the Second Medium-Term Plan (MTP-2) to the Vision 2030 in October 2013. The aim of Kenya's Vision 2030 is to create "a globally competitive and prosperous country with a high-quality of life by 2030" and to shift the country's status to the upper-middle income level. While the improvement in economic performance in the past decade is remarkable, there are indications that achieving such ambitious targets might be difficult, especially given the slow rate of job creation.
Comparing Kenya with similar countries in other regions suggests some relative underperformance in the Kenyan economy. Kenya's economic growth model is driven primarily by the services sector and an over-reliance on the domestic market. This indicates the significant lack of competitiveness of the private sector, which prevents firms from entering and surviving in international markets. It also acts to constrain the potential of the economy in terms of future growth and employment creation. This, combined with accelerating population growth, explains the high levels of youth unemployment in Kenya. New entrants to the labor market-around 20 years of age-face an unemployment rate of around 35 percent. Importantly, while investment has continued to accelerate over the last decade, driven mainly by public investment, aggregate productivity growth turned negative during the 2008-09 economic crisis and during the macroeconomic instability period in 2011, and it has remained stagnant since the 1970s. More importantly, as Figure 1 suggests, aggregate productivity remains around 1980 levels and although the longterm decline experienced in manufacturing has been halted, it has not been reversed over the last decade. Therefore, only by increasing firm productivity can Kenyan firms become globally competitive and generate the quantity of high quality jobs required to boost incomes and achieve shared prosperity. 
Figure 1: Value added (Ksh) per worker, 1969-2010

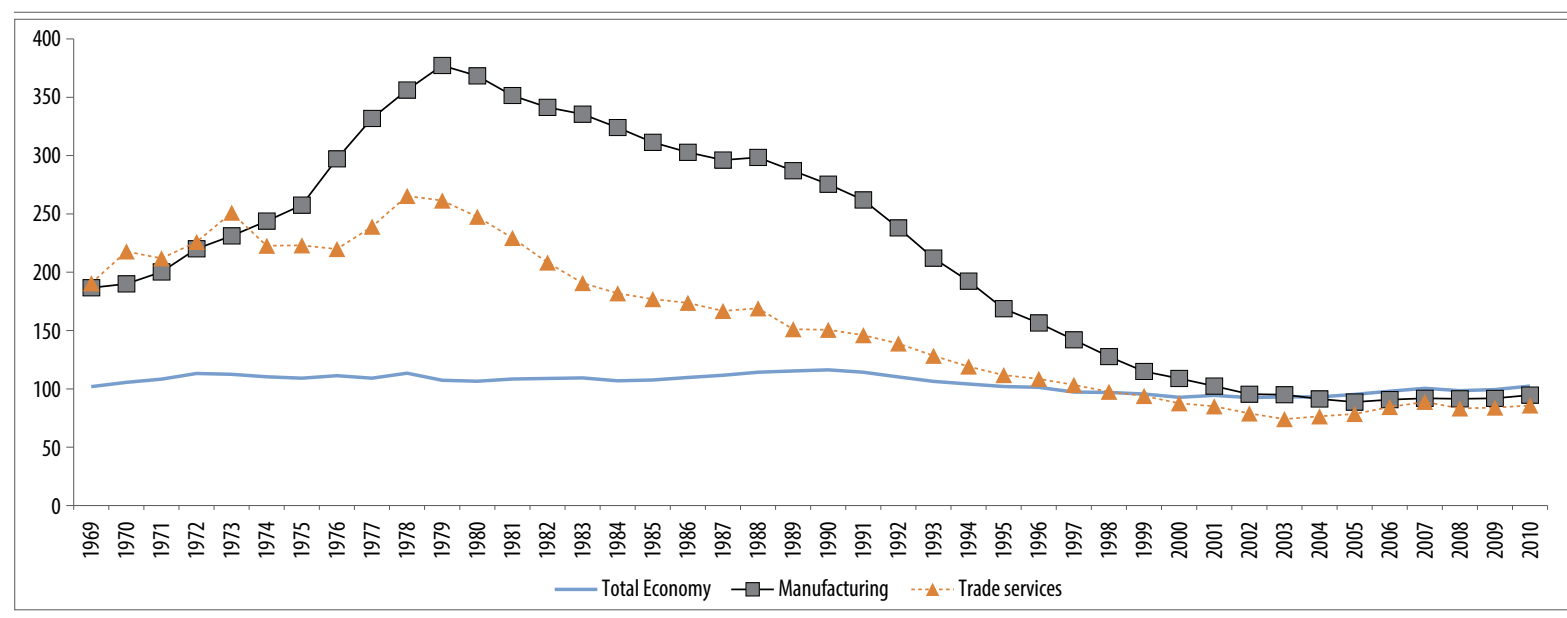

Source: Authors' own elaboration from data from de Vries et al. (2013) 


\section{WHY IS A FIRM-LEVEL PRODUCTIVITY DIAGNOSTIC A USEFUL TOOL FOR POLICYMAKERS?}

\section{Productivity is the best predictor of income per capita}

Eor several years, policymakers and researchers have emphasized the role of factor accumulation to foster economic growth and progress. However, after a decade of empirical research on economic growth, economists concluded that, although physical and human capital accumulation play a crucial role in accounting for economic progress in some countries, total factor productivity (TFP) - a measure of efficiency and technological change-explains the bulk of cross-country differences in both the level and growth rate of per capita GDP (Easterly and Levine 2001). Indeed, at the macro-level, TFP growth in the average country accounts for more than half of output per worker growth. Further, recent empirical evidence shows that the typical Latin American country would have increased income per capita by 54 percent since 1960 if its TFP would have grown at the same pace as its counterparts in the rest of the world (Pages 2010). At the micro-level, evidence has shown that large and persistent differences in productivity levels across businesses are ubiquitous (Syverson 2011).

As Paul Krugman (2014) famously claimed, "Productivity isn't everything, but in the long run it is almost everything. A country's ability to improve its standard of living over time depends almost entirely on its ability to raise its output per worker."Indeed, productivity is also crucial for shared prosperity and poverty reduction as not all transitions from poverty require a change in the type of work undertaken.

In Bangladesh and Vietnam, for example, poverty transitions have been dominated not by changes in income sources from farm to nonfarm income but by higher income within the same sector (Dang and Lanjouw 2012). This is also the case in Sub-Saharan Africa where poverty reduction in rural areas is more closely associated with increases in farm productivity (Christiaensen, Demery, Kuhl 2011). China offers additional insight into this, as increasing labor productivity in agriculture has been a key factor to understanding poverty reduction in lagging Chinese provinces (Christiaensen et al. 2009). In other words, productivity is essential to create better jobs and help households escape poverty, regardless of the sector in which those households work.

\section{Using a firm-level productivity diagnostic improves policymaking}

If productivity is one of the main drivers of competitiveness and a crucial factor for economic growth and poverty reduction, then implementing a sound productivity diagnostic is critical to guide the design and implementation of economic policies. While the initial analysis on productivity was conducted at the industry and/or country level, over the past decade the focus has shifted dramatically towards the firm as the unit of analysis. 
Firm-level productivity diagnostics provide granular information for evidence-based policy-making. Specifically, implementing firm-level productivity diagnostics provide the necessary information for (i) improving the targeting of economic policies, (ii) enhancing their effectiveness, (iii) making more accurate predictions of the effects of industry shocks and policy reforms on the economy, and (iv) for better understanding the behavior of macroeconomic variables by tracking the evolution of variables at the firm-level. More specifically:

- First, firm-productivity diagnostics improve the targeting of economic policies, especially those aimed at enhancing firms' internal capabilities, fostering firms' productivity growth, and facilitating access to international markets.

- Second, firm-productivity diagnostics are important to enhance the effectiveness of economic policies as evidence shows that there is a lot of heterogeneity in firms' attributes and performance even within very narrowly defined industries. This suggests that policies that target the average firm, as was traditionally done in the past, may not end up having the expected impact if the firm productivity distribution is significantly dispersed.

- Third, empirically sound firmproductivity diagnostics allow policymakers to make more accurate predictions about the effects of industry shocks and/or policy reforms on economic performance. For example, a recent study by De Loecker (2011) begs for a serious re-evaluation of a long list of empirical diagnostics that document efficiency responses to industry shocks such as trade liberalization, showing that studies that rely on oversimplifying assumptions to estimate firm-level TFP can overestimate the effects of trade reforms on aggregate productivity.

- Fourth, firm-level productivity diagnostics complement and improve more aggregate analyses as evidence shows that changes in macroeconomic variables, both at the cyclical and secular frequencies, are certainly best understood by tracking the evolution of economic variables at the firm-level (Haltiwanger 2007).

Therefore, when designing or evaluating policies to foster productivity growth and trade, it is very important to determine which firms are going to benefit the most from the proposed policy interventions and which ones may need further assistance. For example, some empirical studies show that productivity-enhancing policies, such as fostering product market competition to ignite innovation, may not have a significant impact on laggard firms if the productivity gap between the top and the worst performer is large (Aghion et al. 2005). Another clear example is export-promotion policies oriented to reduce the fixed cost of exporting. These interventions may not have a significant effect on aggregate exports if productivity dispersion is high and the productivity cutoff, which reflects the minimum efficiency level required to have positive benefits for entering into the export market (e.g., Melitz 2003), is close to the top of the productivity distribution, indicating a large efficiency gap between the median and best firm. 


\section{A guide for policymakers}

The current productivity diagnostic prepared for Kenya is geared to provide policymakers with useful information about the productivity distribution, identifying which are the most productive and unproductive firms. Further, the analysis explores the effects of economic distortions in the prices of factors of production - such as land, labor, and capital -and products on the allocation of labor and capital across firms, as well as their impact on aggregate productivity. The analysis facilitates cross-firm comparisons within a sector and cross-sectoral comparisons within a country. More importantly, it aims at helping the Kenyan Government better target economic policy, more accurately predict the expected impacts of select productive sector policies, and better link macro policies to the real microeconomic dynamics of the productive sector.

Before we start with the analysis, the following sections present a description of the indicators used to implement the diagnostic and their relevance for economic policy. 



\section{THE PRODUCTIVITY DIAGNOSTIC}

\subsection{Some key definitions}

\section{Labor productivity or TFP?}

$T$ here are different measures that can be used to evaluate the efficiency with which firms transform labor, capital, and intermediate inputs into production. The two most commonly used measures are (i) labor productivity and (ii) total factor productivity (TFP).

Although it is reasonable to think that the above mentioned measures must be highly correlated, as efficiency gains obtained through technological change (TFP) will definitively make labor more productive, labor productivity and TFP may not be correlated if productivity gains are obtained through capital accumulation instead of innovation or the adoption of new technologies. Thus, identifying the pattern of productivity growth and economic growth is crucial for policy-making.

\section{Challenges when measuring productivity}

Measuring productivity, strictly defined as the technical efficiency with which firms transform inputs into production, is a challenging task. The most challenging issue is disentangling technical efficiency from other supply and demand-side determinants that affect firm sales-the variable commonly used to measure production when product prices are not available.
On the supply-side, these determinants might include adjustment-costs, mark-ups, and policy distortions that impact the price of different factors of production (such as land, labor, and capital), which ultimately affect the relative marginal cost of production and therefore, the final price of products. On the demand-side, those determinants might involve mark-ups, quality-upgrading, and product price distortions (e.g., taxes), which affect final product prices. The risk is, therefore, that one measures as physical productivity parameters that are not strictly related to technical efficiency but to the characteristics of the market structure in which firms operate or to the economic policy distortions that can affect both the relative price of inputs and the final price of products.

If data on prices is available at the plant or firm-level, then the best measures to capture labor productivity are (i) deflated sales (output) per worker or value-added per worker, and/or (ii) deflated sales (output) per hour worked or value-added per hour worked. The best measure to capture TFP is "physical TFP or TFPQ", defined as the deflated value of sales (output) minus the contribution of labor and capital (it could also exclude the contribution of materials, too).

In practice, since firm prices are often not available in the data, sales per worker, sales per hour worked, revenue TFP or TFPR, and physical TFP are the most commonly 
used measures to capture productivity. Although labor productivity and TFPR will not exclusively reflect a firm's technical efficiency, they are good indicators of the level of competitiveness of a firm in a market.

Even if one observes output prices, in order to obtain a good measure of physical productivity, we also need to control for differences in input prices. In the absence of input prices, TFP estimates using revenue as output can provide more accurate estimates than estimates obtained when only output is correctly deflated since the impact of prices on outputs and inputs tend to cancel out. In order to compare the different productivity measures in this analysis, we use one labor productivity indicator (value added per worker) and three proxies of TFP representing three different methods. (Box A1 in the Appendix provides their definition.)

The first TFP measure (TFP-est) represents the residual of estimating a traditional CobbDouglas production function of sales on factors costs. In essence, this is the portion of output not explained by the contribution of intermediate inputs, land, labor, and capital used in production. As such, its level is determined by how efficiently those inputs and factors of production are utilized. This measure presents several caveats:

1. Assuming the same and Hicks-neutral technology for broadly defined sectors;

2. "Simultaneity Bias" as input choices may not be independent of firm characteristics, including efficiency, which is assumed using Ordinary Least Squares to estimate TFP-est;

3. "Omitted Output Price Bias" as absence of information on product prices can introduce a bias in the estimated coefficients if the market structure in which firms operate is not perfectly competitive, meaning that firm prices will deviate from industry prices or GDP deflators, which are usually the variables used to deflate nominal values;

4. "Omitted Input Price Bias" as lack of data on factor prices can introduce a bias in the estimated coefficients because in the presence of imperfect competition in input markets, input prices are likely to be firm-specific;

5. "Endogeneity of the product-mix" as ignoring the multi-product dimension of some firms implies an assumption of the same technology for all products produced by a firm.

The second and third measures of TFP employed are based on the Hsieh and Klenow (2014) framework implemented in Cirera et al. (2015).Under some specific and strong assumptions about demand (e.g., constant mark-ups for all firms) and production (e.g., constant returns to scale and absence of adjustment costs), these measures allow firms' optimal input choices to be used to calculate revenue productivity (TFPR), which is de facto a measure of firm-specific distortions and physical efficiency (TFPQ). The criticism of this framework relies on the strong assumptions mentioned. The main implication of this approach is that dispersion in TFPR is strictly attributed to economic distortions at the firm-level, while the truth is that heterogeneity of firm performance or marginal products of labor and capital can be perfectly explained by mark-ups, demand shocks, and/or adjustment costs. 
The advantage of using this set of four productivity variables is that it allows us to compare them when building the productivity diagnostics for the economy.

\section{The static productivity analysis}

The static productivity analysis is geared to evaluate the within and the between component of aggregate productivity. The within component is related to individual firms becoming more productive; that is, increasing the amount of output they produce with a constant amount of inputs. The between component is associated with the reallocation of factors of production and economic activity toward more productive firms. The latter component is associated with static allocative efficiency, which is captured by the fact that firms with higher than average productivity in a particular sector or economy should have a larger than average size in the sector or the economy (usually measured through employment or sales share). Lack of static allocative efficiency suggests misallocation of resources across firms, and it can have important negative effects on aggregate productivity at the sectoral and economy level (Restuccia and Rogerson 2008; Hsieh and Klenow 2009; Alfaro, Charlton, Kanczuk 2008; Midrigan and Yi Xu 2010).

\subsection{Kenya productivity diagnostic}

\subsubsection{INDICATORS TO ANALYZE WITHIN- FIRM PRODUCTIVITY}

We start this section by providing a set of indicators that are relevant for both (i) targeting economic policies in order to enhance firms' capabilities, improve firm productivity, and foster economic growth, and (ii) predicting the impact of economic policies.

The data used for the analysis corresponds to the 2010 Census of Industrial production and the 2011 Integrated Survey of Services (see Box 1). These are the two more extensive sources of information for firms in the Kenyan economy, with around 5,000 observations including both datasets.

\section{Box 1: Data sources}

The 2010 Census of Industrial Production

The 2010 Census of Industrial Production is a survey jointly realized by KNBS and the Ministry of Industrialization. Reporting information for 2,252 firms (1,814 firms responded and information for 438 others have been imputed on other regular surveys), this survey gathered information relating to the calendar year 2009, although some information is available for 2010. Targeted firms belong to ISIC Rev 4 sections B (Mining and quarrying), C (Manufacturing), D (Electricity, gas, steam and air conditioning supply) and E (Water supply, sewerage, waste management and remediation activities).

We focus the analysis on firms belonging to the manufacturing sector. 


\section{The 2011 Integrated Survey of Services}

The 2011 Integrated Survey of Services focuses on businesses in the service sector in 2009/2010 fiscal year. KNBS collected data on 3191 formal services firms (over 4464 targeted), spread across 13 different service subsectors (following ISIC rev.4).

Some data cleaning has been performed in order to cope with the low quality of the data. Firms reporting an activity which does not belong to the usual services category have been excluded from the sample. Also, firms reporting total employment levels (including the owners of the firms) equal to 0 have been excluded from the sample.

\section{a) Aggregate indicators}

\section{i. The productivity distribution}

The starting point is to summarize the entire set of firms' productivity data points, that is, the productivity distribution. The Kernel density presented in Figures 2-5 represents the productivity distribution function and serves to have an overall view of the degree of productivity heterogeneity and/or dispersion across firms. Each figure uses a different measure of productivity to compare the productivity of firms in the Kenyan services sector, the manufacturing sector, and in the aggregate. It is useful to briefly review the different measures of productivity:

- Log of $\mathrm{Va} / \mathrm{L}$ is labor productivity, measured as the value-added of labor
- Log of TFP Est is the proportion of output not explained by the estimated contribution of factors of production such as labor and capital

- Log of TFPR is total factor productivity of revenue, measured based on firm sales

- Log of TFPO is total factor productivity of physical efficiency, measured based on the deflated value of sales minus the contribution of labor and capital.

Information about the distribution of firms' productivity such as the maximum and minimum productivity, the degree of dispersion among firms' productivity, or comparisons between the bottom 25 percent of firms and the bottom 50 percent, the median firm, or the bottom 75 percent of firms can be very useful as a first summary of the data. 
Figures 2-5: Productivity distributions

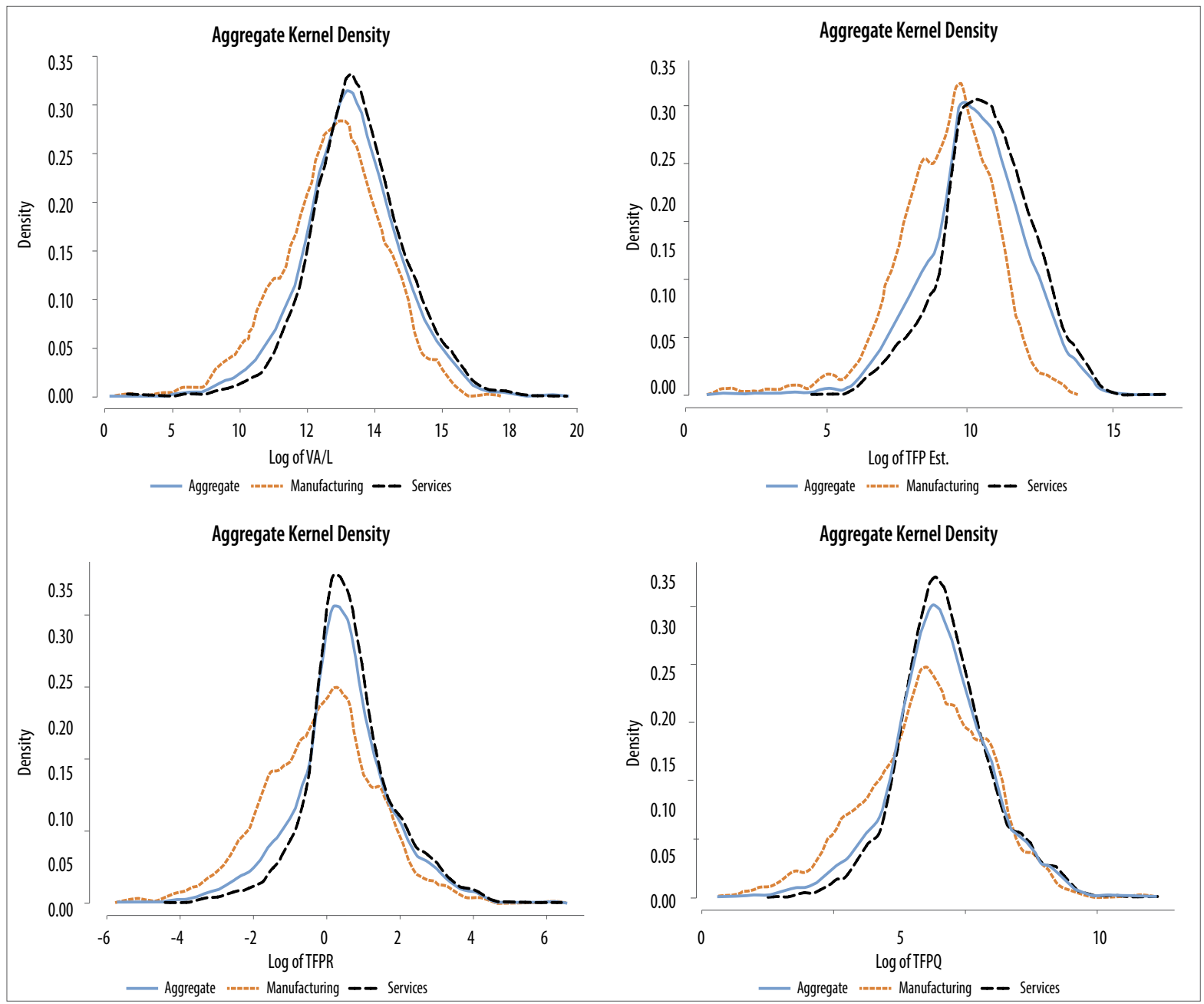

Source: Authors' own elaboration from Census of Industrial Production and Integrated Survey of Services

Services firms appear to be more productive than manufacturing

The main conclusion that can be drawn from Figures 2-5 is that firm-level productivity in Kenya is lower in the manufacturing sector than in the services sector, providing microeconomic foundations that rationalize why Kenya's manufacturing sector is small relative to the services sectors. The relatively poor productivity performance of firms in the manufacturing sector is one of the factors explaining why the overall activity of the manufacturing sector over the past seven years was disappointing, with manufacturing growth (3.1 percent) significantly lagging behind overall economic growth (5.0 percent).

The left tail of the productivity distributions, which is far thicker in the manufacturing sector than in the services sector, may be indicative of the existence of policies favoring the survival of inefficient firms in the manufacturing sector relative to the services sector. Indeed, there are indications that firms in the manufacturing sector are operating well below their full capacity (Cirera, 2015). 
Table 1 shows the correlation among the different measures of productivity. The high correlation between labor productivity (VA/L)and physical TFP(TFPO), for example, suggests that labor efficiency gains in Kenya are most likely obtained through technological change-including innovation and technology adoption-rather than accumulation of capital. Indeed, a recent World Bank Group report by Cirera (2015) highlights that firm-level innovation rates in Kenya are relatively high as compared to international standards, and they also generate significant revenues. Nevertheless, the innovation activity is often related to marginal improvements in the quality of existing goods rather than radical innovations such as the creation of new products that are breakthroughs to the national and/or international markets.

Table 1: Correlation between productivity measures

\begin{tabular}{|l|c|c|c|c|}
\hline & VA/L & TFPQ & TFPR & TFP Est. \\
\hline VA/L & 1.000 & 0.766 & 0.616 & 0.754 \\
\hline TFPQ & 0.766 & 1.000 & 0.878 & 0.723 \\
\hline TFPR & 0.616 & 0.878 & 1.000 & 0.716 \\
\hline TFP Est. & 0.754 & 0.723 & 0.716 & 1.000 \\
\hline
\end{tabular}

Note: correlations are statistically significant at the $5 \%$ level.

\section{ii. Stretched vs. squeezed distributions}

The second indicator is productivity dispersion, which can be defined as (i) the standard deviation of the productivity distribution, (ii) the inter-quartile ratio (bottom 75 percent of firms versus the bottom 25 percent), and (iii) the ratio between the bottom 90 percent of firms and the bottom 10 percent, after removing outliers. These indicators provide information about how stretched or squeezed the productivity distribution is.
This is important for policy-making for at least two reasons. First, as we will see later, dispersion in revenue TFP (TFPR) may reflect the existence of economic distortions in factor prices and product prices that negatively affect aggregate productivity at the sectoral level. It may also capture market-power and/or adjustment costs, which prevent the growth of small firms once they enter the market. Second, dispersion indicates the need to design tailored policies for different segments of the productivity distribution, as targeting the average firm may not have the desired impact if there is a lot of heterogeneity in performance across firms.

Table 2 takes the four measures of productivity, and within that the measures among the manufacturing firms, the services firms, and the firms in aggregate, and shows their degree of productivity dispersion across three different indicators: standard deviation, bottom 75 percent vs. bottom 25 percent, and bottom 90 percent vs. 10 percent. The larger the resulting number, the larger the dispersion.

Table 2: Productivity dispersion (logs)

\begin{tabular}{|l|l|c|c|c|}
\hline & Log productivity & SD & $\mathbf{7 5 / 2 5}$ & $\mathbf{9 0 / 1 0}$ \\
\hline VA/L & Aggregate & 1.34 & 1.141 & 1.298 \\
\hline VA/L & Manufacturing & 1.385 & 1.157 & 1.346 \\
\hline VA/L & Service & 1.282 & 1.134 & 1.277 \\
\hline TFPQ & Aggregate & 1.761 & 1.272 & 1.658 \\
\hline TFPQ & Manufacturing & 2.019 & 1.387 & 1.935 \\
\hline TFPQ & Service & 1.636 & 1.244 & 1.556 \\
\hline TFPR & Aggregate & 1.208 & 0.576 & 1.394 \\
\hline TFPR & Manufacturing & 1.359 & 0.813 & 1.609 \\
\hline TFPR & Service & 1.09 & 0.536 & 1.227 \\
\hline TFP Est. & Aggregate & 1.615 & 1.224 & 1.541 \\
\hline TFP Est. & Manufacturing & 1.451 & 1.26 & 1.507 \\
\hline TFP Est. & Service & 1.54 & 1.213 & 1.473 \\
\hline
\end{tabular}

Source: Authors' own elaboration from Census of Industrial Production and Integrated Survey of Services 


\section{Worse functioning and more distorted markets in the manufacturing sector}

Table 2 shows that productivity dispersion is larger in the manufacturing sector than in the services sector. Further, evidence for Kenya is in line with previous productivity studies, both for developing and developed countries, which show that the dispersion of physical TFP (TFPQ), a true measure of efficiency, is larger than the dispersion of revenue TFP (TFPR), a measure of market performance. This suggests that more efficient firms in Kenya set lower product prices than inefficient firms, implying that productivity gains can be welfare improving.
Figures 6 and 7 show productivity dispersion among the top 10 manufacturing and services subsectors, ranked by their size measured by the contribution to total value-added. They show both the standard deviation (SD) within each subsector and the inter-quartile range, which is also another measure of statistical dispersion, equal to the difference between the upper and lower quartiles, $I Q R=Q 3-\mathrm{Q} 1$. Dispersion is high in sectors such as manufacturing of electrical equipment, chemicals, and fabricated metal products (Figure 6). The same occurs with travel agency activities, financial services, and social work activities in the services sectors (Figure 7).

Figure 6-7: Productivity dispersion

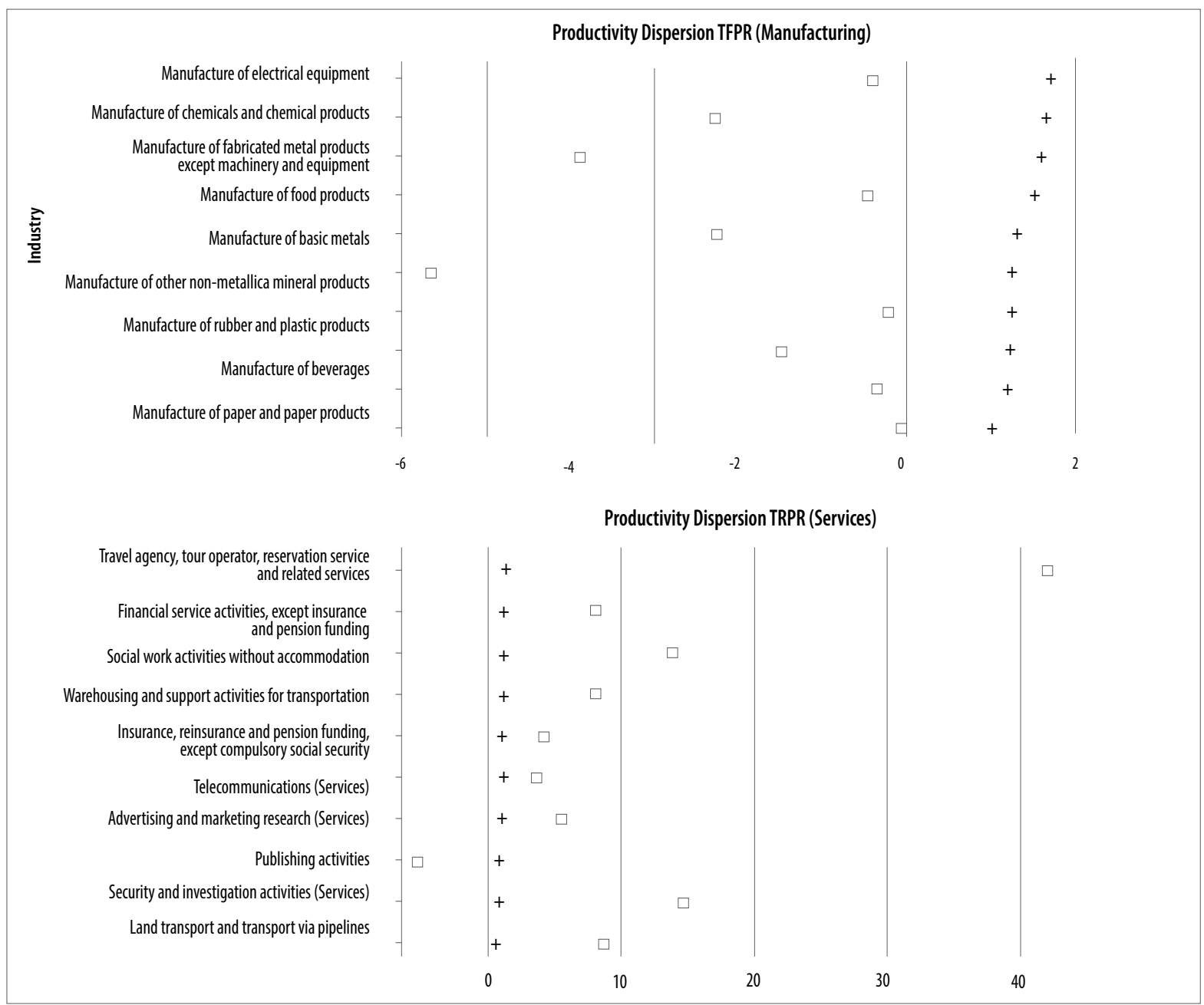


These large and high dispersion sectors provide a first list of priority sectors for tailored policy interventions, since understanding and removing the distortions that create this wedge in firms' performance could have important benefits in terms of productivity and employment growth.

\section{Technological gaps are larger than labor efficiency gaps}

Further, dispersion of labor productivity is smaller than dispersion of TFPQ, suggesting that the technology gap between leading and laggard firms is larger than the labor efficiency gap. The immediate implication of this empirical regularity, which applies to both the manufacturing and services sectors, is that policies geared to foster technical change, such as innovation policies (e.g., tax incentives, matching grants, royalties) or policies oriented to facilitate technology adoption (e.g., subsidies for the adoption of new technologies), should be more firm-specific than policies aimed at increasing valueadded per worker through the accumulation of capital (e.g., subsidies to credit).

\section{Productivity dispersion is much larger in the Kenyan manufacturing sector than in other countries}

A comparison of dispersions in TFP with other countries such as China and India, or other African countries such as Ethiopia and Ghana (Cirera et al. 2015), shows a much larger dispersion of technical efficiency in Kenya than in the rest of the countries for both TFPO and TFPR. This implies, as we will see below, that distortions in the manufacturing sector in Kenya are pervasive. iii. Symmetric vs. asymmetric distributions

A third aggregate indicator is the skewness of the distribution, which quantifies how symmetric the distribution is. For a unimodal distribution, a negative skew indicates that the tail on the left side of the probability density function is longer than the right-hand side, showing a large proportion of firms with low productivity levels surviving in the market, compared to the proportion of firms with high productivity. In this situation, the mean (or average) is less than the mode (or maximum point of the curve), compared with the case of a normal distribution, where the mean and mode are equal. A normal distribution, which is symmetric, has zero skewness and the tails on either side of the curve are exact mirror images of each other. Conversely, a positive skewed curve indicates that the tail on the right-hand side is longer than the tail on the left-hand side, and the mean is greater than the mode, showing a small proportion of firms with low productivity levels surviving in the market, compared to the proportion of firms with high productivity.

Figure 8 shows the skewness of the productivity distribution for both manufacturing and services, across the four measures of TFP.

\section{More efficient firms tend to coexist in the services sectors}

Figure 8 shows that the productivity skewness in the services sector for measures like TFPQ and TFPR is positive, indicating a longer tail to the right-hand side than to the left-hand side, with more efficient firms surviving in the Kenyan services sector. The negative skewness measure 
in the manufacturing sector for almost all productivity measures suggests a longer lower productivity tail (left-hand side) than the high productivity tail (right-hand side), another indication of potential misallocation in the sector.

Figure 8: Skewness

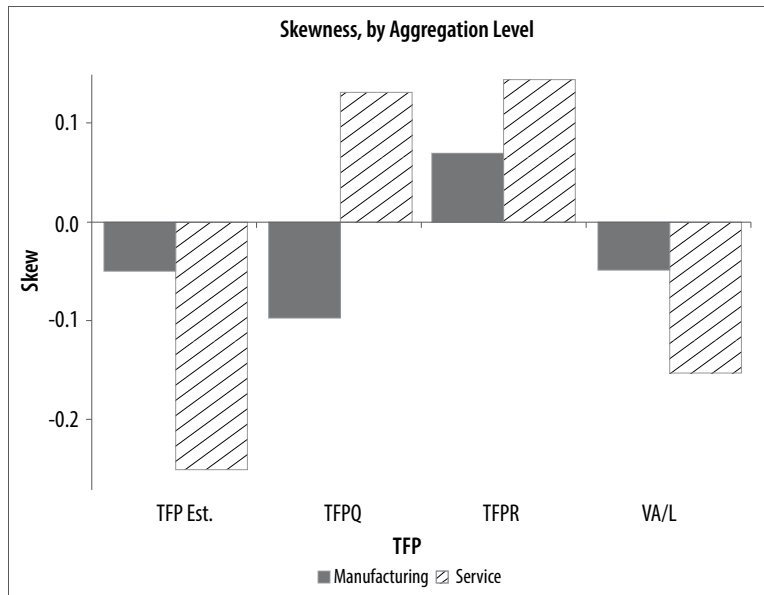

Source: Authors' own elaboration from Census of Industrial Production and Integrated Survey of Services

\section{iv. Productivity gap (leaders vs. laggards)}

The last indicator we explore is the median distance to the frontier, measured as the median value of the ratio between the productivity level of each firm and the productivity level of the top performer. This measure provides crucial information about the productivity gap between the median firm and the best performer. Table 3 shows this indicator across the four productivity measures, and within each, across manufacturing firms, services firms, and firms in the aggregate. The higher the number, the higher the productivity gap. The gap appears to be relatively high, especially in the manufacturing sector.
Table 3. Distance to the national productivity frontier

\begin{tabular}{|l|l|c|}
\hline \multirow{4}{*}{ VA/L } & Aggregate & $\begin{array}{c}\text { Median distance to } \\
\text { frontier }\end{array}$ \\
\cline { 2 - 3 } & Manufacturing & 3.865 \\
\cline { 2 - 3 } & Service & 4.357 \\
\hline \multirow{4}{*}{ TFPQ } & Aggregate & 3.547 \\
\cline { 2 - 3 } & Manufacturing & 4.536 \\
\cline { 2 - 3 } & Service & 4.738 \\
\hline \multirow{4}{*}{ TFPR } & Aggregate & 4.48 \\
\cline { 2 - 3 } & Manufacturing & 3.362 \\
\cline { 2 - 3 } & Service & 3.711 \\
\hline \multirow{4}{*}{ TFP Est. } & Aggregate & 3.254 \\
\cline { 2 - 3 } & Manufacturing & 3.774 \\
\cline { 2 - 3 } & Service & 3.826 \\
\hline
\end{tabular}

Source: Authors' own elaboration from Census of Industrial Production and Integrated Survey of Services

There is a large productivity gap in Kenyan firms, especially in the manufacturing sector

In the case of Kenya, Table 3 shows two important things. First, that the labor productivity gap between leading and laggard firms is smaller than the technical efficiency gap. This may be explained by a combination of factors, including the highly concentrated rates of investments in innovation, which was recently documented by Cirera (2014), and the random nature of the innovation process, which makes some firms luckier than others in creating new products and/or processes or improving the quality of existing goods. In other words, this fact shows that labor is more or less similar in their levels of productivity across different types of firms, but the real difference comes in the efficiency with which firms use their labor force, which is an issue related to innovation and access to new technologies. This fact is in line with the issue that economic growth in Kenya is related to 
innovation and technology adoption rather than accumulation of capital. Second, Table 3 shows that the distance to the frontier is significantly larger when measured through physical TFP (TFPQ) than through revenue TFP (TFPR). The latter is logical because adjustments in prices due to efficiency gains reduce the revenue performance gap between leaders and laggards.

These results are very important for policymaking for several reasons highlighted below:

- First, evidence shows that productivityenhancing policies, such as fostering product market competition to ignite innovation, are unlikely to have a significant impact on laggard firms if the productivity gap between leaders and laggards is large. In the case of Kenya, this is likely to be the case, especially in the manufacturing sector.

- Second, if the productivity gap is a good proxy of the gap in the absorptive capacity of firms, then policies oriented to increase laggard firms' productivity may be inefficient to boost the efficiency level of low productivity firms. In other words, laggard firms in Kenya are unlikely to have enough capacity to benefit from policies to support innovation and could benefit more from policies that support basic management and organizational skills.

- Third, export-promotion policies oriented to facilitate access to international markets by reducing the fixed cost of exporting may not have a significant impact on aggregate exports if the minimum efficiency level required to cover the fixed cost of exporting is high. b) Who are the most productive and unproductive firms?

Once productivity measures have been calculated and the productivity distribution examined, the second step in the analysis involves examining the links between productivity and firm characteristics or attributes, such as size, age, export status, import status, R\&D intensity, and type of ownership. Identifying the most productive and unproductive firms is crucial to target economic policies aimed at boosting economic growth.

\section{i. Average of log-productivity by percentile of firm characteristic}

Figures 9-12 compare the productivity of firms according to their size, across the four measures of productivity. The horizontal axis measures size by deciles (the smallest 10 percent of firms, the smallest 20 percent, the smallest 30 percent, etc.), while the vertical axis shows average productivity. An upward sloping line means productivity increases with firm size, while a downward sloping line means it decreases with size.

The most important message provided by Figures 9-12 is that productivity performance varies across firms, depending on their size. However, the direction of the difference between size groups depends on the type of productivity measure being considered. First, the figures show that there are not significant differences in labor productivity across firms of different size, although small firms tend to produce more value-added per worker than large firms. However, large firms tend to display a better performance than small firms in terms of technical efficiency, which may be explained by the fact that large firms 
Figures 9-12: Productivity and firm size

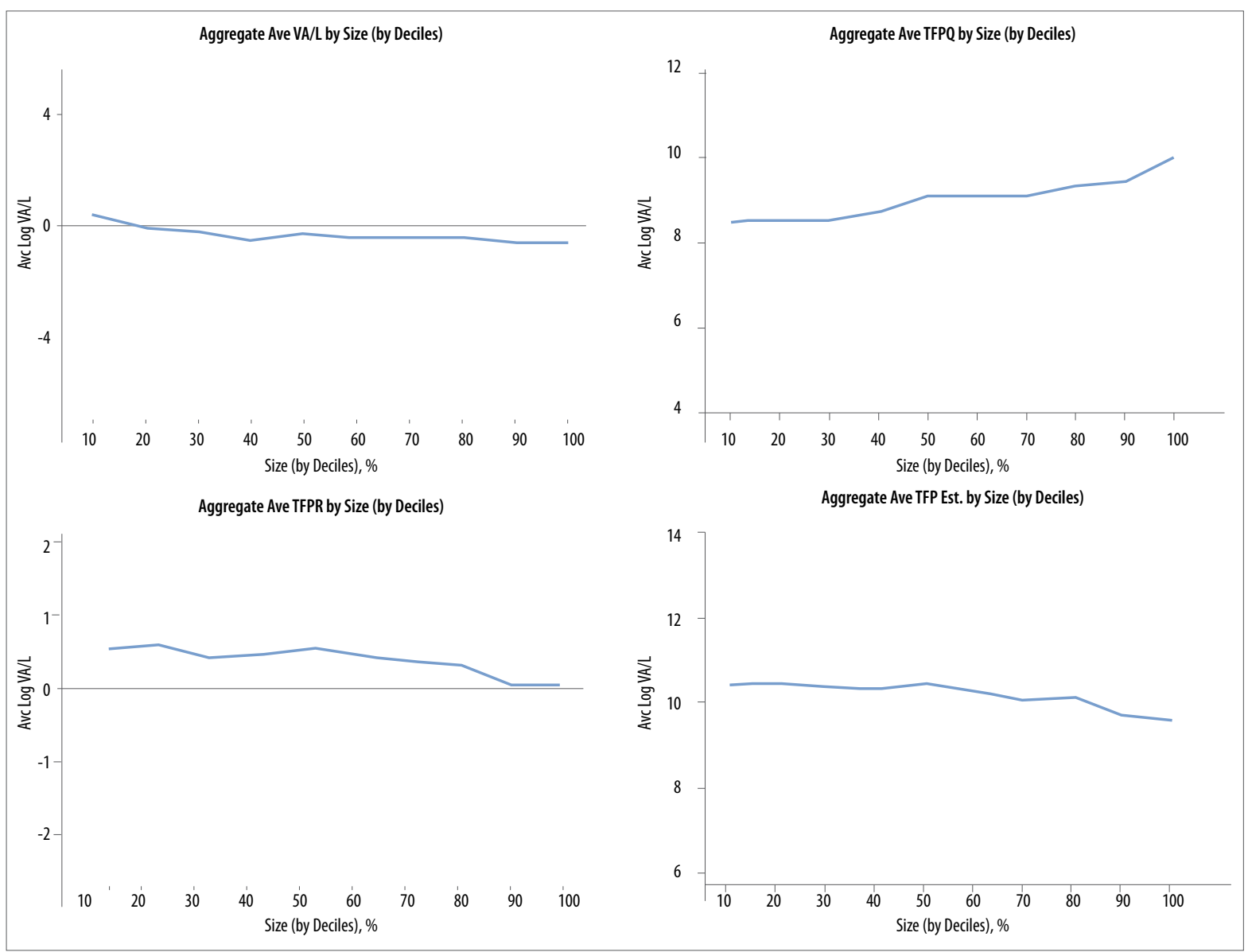

Source: Authors' own elaboration from Census of Industrial Production and Integrated Survey of Services

are more capable of overcoming the large fixed costs of innovating as they can usually have better access to external sources of innovation finance than small firms.

A comparison of innovation activities at the firm-level in Kenya shows that medium-sized and large firms are more innovative than small companies (Cirera 2014). Interestingly, small firms display larger revenue TFP than large companies. However, this does not necessarily mean that they are more efficient, as this variable may be contaminated with mark-ups, adjustment costs, and product and factor price distortions. The result may reflect that economic distortions disproportionately and favorably affect small firms, although these companies are not the most efficient.

Figures 13-16 compare the productivity of manufacturing firms according to their age, across the four measures of productivity. These figures show that mature firms are more productive in terms of labor and technical efficiency than young firms in the manufacturing sector. ${ }^{3}$ However, revenue TFP is larger for young firms, suggesting that distortions have a larger and favorable impact on these firms. 
Figures 13-16: Productivity and firm age

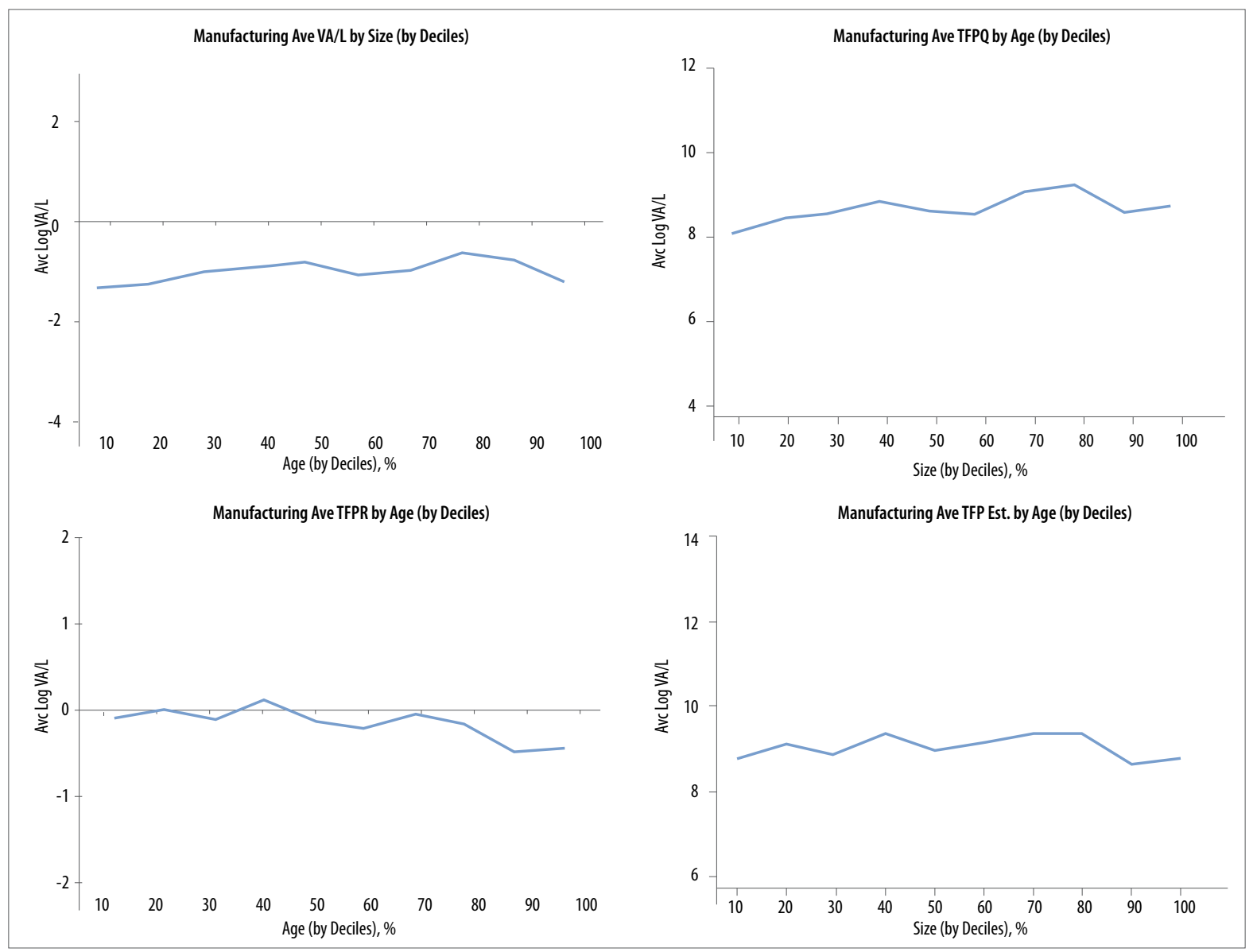

Source: Authors' own elaboration from Census of Industrial Production and Integrated Survey of Services

ii. Cumulative distribution functions by group

\section{Exporters are more productive than non- exporters}

In addition to the previous graphs that allow us to explore productivity heterogeneity across firms' groups, plotting cumulative distribution functions by type of firms is very informative to heterogeneity. Figures 1720 show the cumulative distribution of firm productivity by firms' export status (exporters and non-exporters), according to the four measures of productivity. The further apart the two curves are, the greater the difference in productivity levels between exporters and non-exporters. Conversely, the closer the curves are to each other, the smaller the differences.

Figures 17-20 show that the productivity performance of exporting firms is larger than that of non-exporting firms. This fact can be the result of both static and dynamic efficiency gains. Evidence shows that most productive firms are the ones able to cover the fixed cost of exporting and entering into international markets. At the same time, access to international markets can create learning-by-doing effects that make firms more efficient and/or allow them to absorb knowledge spillovers, which help them to become more competitive. 
Figures 17-20: Cumulative Distribution Function (CDF) and export status

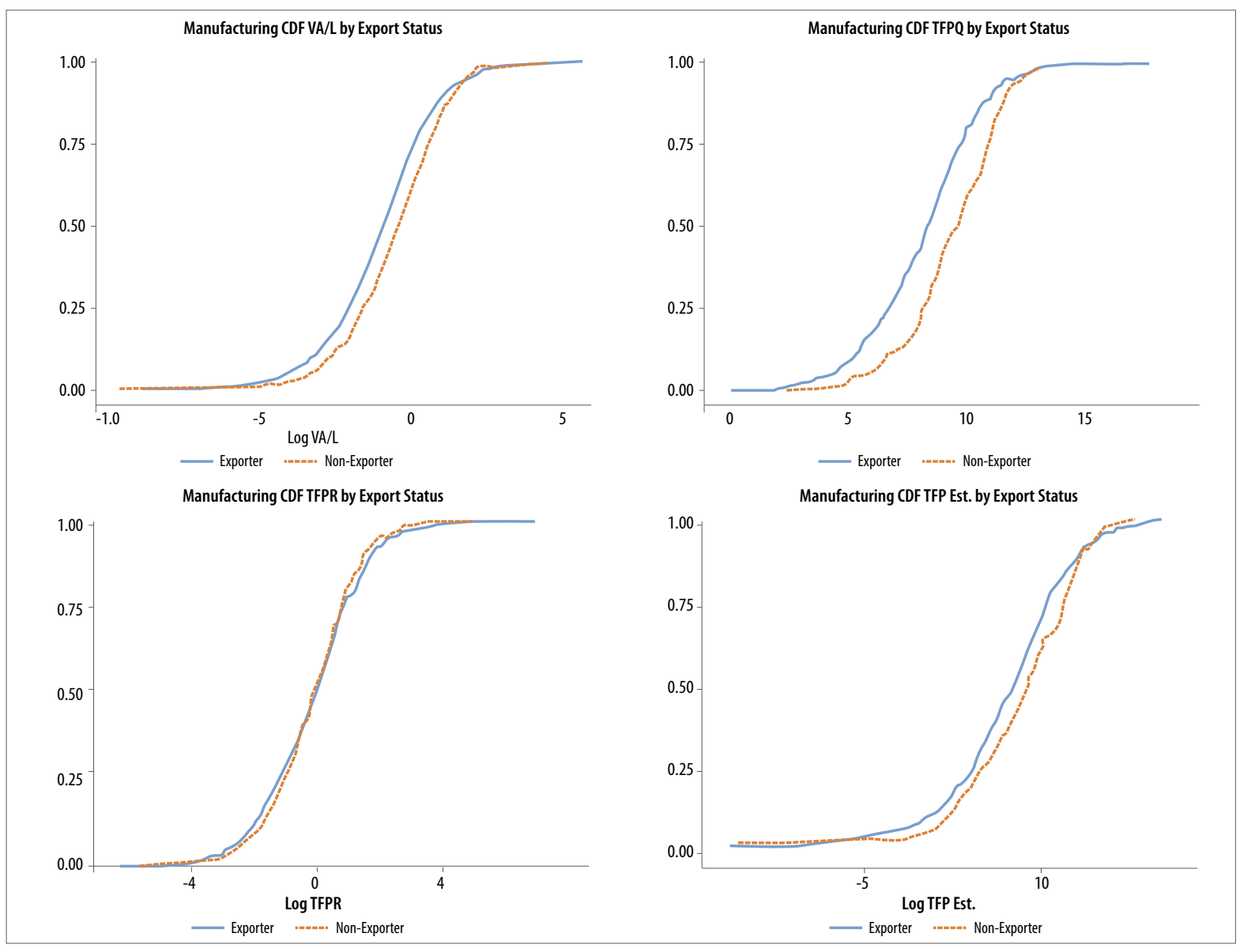

Source: Authors' own elaboration from Census of Industrial Production and Integrated Survey of Services

The productivity gap between exporters and non-exporters is larger when both groups are compared according to their technical efficiency, suggesting that investments in technological change (e.g., innovation and technology adoption) can be more effective than investments in capital to help firms achieve the minimum level of efficiency required to overcome the fixed costs of exporting. Interestingly, there are no significant differences between exporters and non-exporters when measuring productivity through TFPR, suggesting that the pass-through of efficiency gains to final prices obtained by exporting firms, probably ex-ante to enter into international markets, is high. Alternatively, the lack of differences between both distributions may reflect the fact that non-exporting firms face relatively more distortions than exporting firms.

The Kolmogorov-Smirnov Test (KST) is a non-parametrical test of the equality of continuous and one-dimensional probability distributions that can be used to compare two samples. In the particular case of Figures 17-20, the KST is used to compare how equal the exporter and non-exporter curves are to each other. The Kolmogorov-Smirnov statistic quantifies the distance between the empirical distribution functions of exporters and non-exporters. The null hypothesis is 
that the samples are drawn from the same distribution, which means that the productivity distribution of exporters and non-exporters are not statistically different from each other.

The information provided by the KST can also be complemented with a First-order Stochastic Dominance Test (FSDT), which evaluates differences across groups (e.g., exporters and non-exporters) by examining differences in the cumulative distribution functions of the variable of interest (e.g., productivity). According to the definition, productivity distribution A (e.g. exporter) "first-order stochastically dominates" productivity distribution B (e.g., non-exporter) if and only if for any productivity value " $x$ ", the cumulative distribution function $F B(x) \geq F A(x)$. Visually, A dominates stochastically $B$ if the productivity cumulative distribution function of $A$ is, for all " $x$ " values, to the right of $B$, meaning that the proportion of firms with productivity values " $x$ " in $A$ is always no smaller than the proportion of firms in $B$ (e.g., $\operatorname{Prob}(A \geq x) \geq(\operatorname{Prob}(B \geq x))$, which reflects that overall, firms in group $A$ have a better productivity performance than firms in group B.

Table 4 shows the results of those tests. Column (4) provides the statistical p-value associated with the null-hypothesis of the KST. P-values lower than 0.05 mean that the KST rejects the null hypothesis that the productivity distributions across the two groups are statistically equal. Column (5) provides information of whether one group first-stochastically dominates the other. Table 4 confirms that the productivity of exporters is larger than that of non-exporters, except when productivity is measured with TFPR.

\section{iii. Relative productivity cumulative distributions functions between groups}

\section{Mature firms are not necessarily more efficient than young firms}

Productivity differences can also be examined by drawing the productivity relative cumulative distribution function (PRCDF) and comparing it with the 45 degree line. Figures 21 to 25 show the relative CDFs of young vs. mature firms, across the four measures of productivity. To infer conclusions about the figures, there are a couple of simple rules that can be applied:

- First, the farther the distance between the PRCDF curve and the 45 degree line, the farther the productivity differences between both groups.

- Second, if the PRCDF curve is below the 45 degree line, then the group represented on the $Y$-axis (mature firms) has a better productivity performance than the group represented on the $X$-axis (young firms), as a smaller percentile in $\mathrm{Y}$ has the same productivity

Table 4: Kolmogorov-Smirnov test results

\begin{tabular}{|l|l|l|c|c|}
\hline & \multicolumn{1}{|c|}{ Group 1 } & \multicolumn{1}{|c|}{ Group 2 } & $\begin{array}{c}\text { P-Value null: CDFs are } \\
\text { equal }\end{array}$ & $\begin{array}{c}\text { Which group } \\
\text { stochastically } \\
\text { dominatesthe other? }\end{array}$ \\
\hline$(1)$ & $(2)$ & $(3)$ & $(4)$ & (5) \\
\hline Manufacturing, VA_L & Exporter & Non-Exporter & 0.00 & Group 1 \\
\hline Manufacturing, TFPQ & Exporter & Non-Exporter & 0.00 & Group 1 \\
\hline Manufacturing, TFPR & Exporter & Non-Exporter & 0.61 & Neither \\
\hline Manufacturing, TFP2 & Exporter & Non-Exporter & 0.01 & Group 1 \\
\hline
\end{tabular}

Source: Authors' own elaboration from Census of Industrial Production and Integrated Survey of Services 
level than a larger percentile in $\mathrm{X}$. The reverse applies when the PRCDF curve is above the 45 degree line: the group represented on the $X$-axis (young firms) has a better productivity performance than the group represented on the $Y$-axis (mature firms).

- Finally, if the PRCDF is below the 45 degree line and never cross it, then the PCDF of the group represented in the $\mathrm{Y}$-axis (mature firms) stochastically dominates the PCDF of the group represented in the $\mathrm{X}$-axis (young firms).

The Figures show that mature firms are more efficient than young firms in the case of value added per worker (VA/L) and TFPQ, but only in the middle of the distribution. In the case of TFPR and TFP estimated, young firms are more efficient in some parts of the distribution.

Figures 21-25: Relative Cumulative Distribution Function (CDF) and firm age
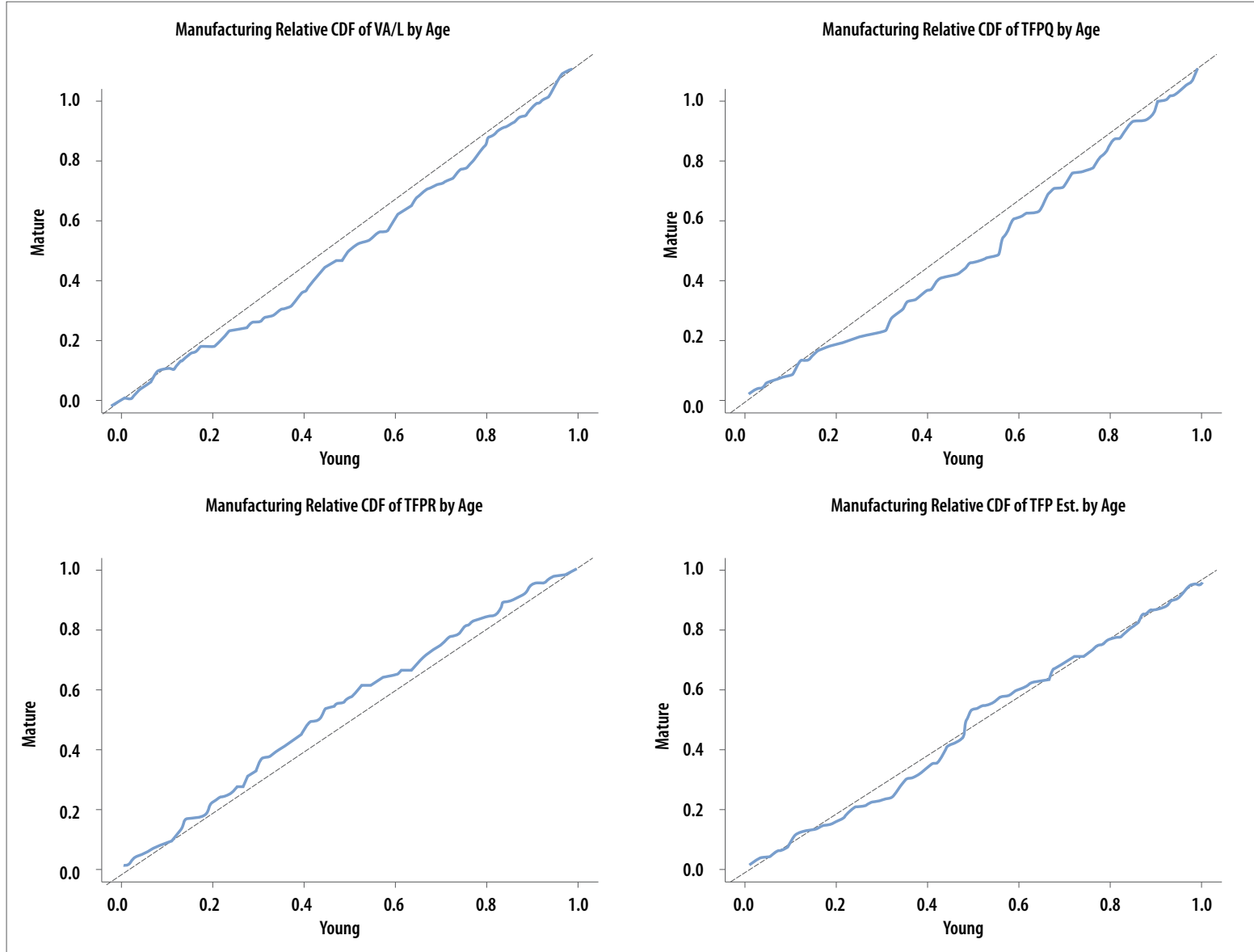

Source: Authors' own elaboration from Census of Industrial Production and Integrated Survey of Services 


\subsubsection{EXPLORING ALLOCATIVE EFFICIENCY}

We start this section by dividing indicators in two categories: indirect and direct measures of allocative efficiency. Recall that an economy displays allocative efficiency when firms that show a productivity performance above the average/median productivity in a particular industry are larger than the average/median productivity firm in the same industry. By contrast, misallocation of resources occurs when productive firms are smaller in terms of factor and market shares than unproductive firms.

Exploring allocative efficiency is important because misallocation can have negative economic effects at the aggregate level. Empirically, economies with low allocative efficiency tend to suffer from the following characteristics: (i) low rates of firm entry and exit; (ii) low post-entry growth rates of efficient firms; (iii) high firm-level productivity dispersion, even within very narrowly defined industries; (iv) low correlation between size (measured through employment shares or market shares) and firm-level productivity; and $(v)$ higher employment growth in mature firms than in young firms.

\section{Indirect measures of allocative efficiency}

The first indirect measure of misallocation is the dispersion of revenue TFP (physical productivity multiplied by a firm's output price). As suggested above, Hsieh and Klenow (2009) have presented a framework where optimal input choices are directly informative about the efficiency with which labor and capital are allocated across firms. The analytical framework used by the authors identifies the level of misallocation of labor and capital in an industry from the variation in marginal products of these factors across firms. As such, the marginal product of labor measures the marginal change in output per marginal change in labor, while conversely, the marginal product of capital measures the marginal change in output per marginal change in capital. This framework has been used extensively. However, recent research shows that in dynamic settings, other reasons like volatility in sales coupled with adjustment costs in capital could also explain productivity dispersion (Asker, Collard-Wexler, De Loecker 2014).

A simple way of examining the dispersion of revenue TFP is to make a box-plot representation of the variable as per Figure 26. The box represents the productivity levels between the bottom 75 percent of firms and the bottom 25 percent of firms, with the top part of the box representing the 75 percentile, the bottom part the 25 percentile, and the line inside the box the median productivity level. The dots reflect the productivity outliers, that is, firms with an extraordinary good productivity performance (if they are above the box) or an extraordinary bad performance (if they are below the box).

Figure 26: Box Plot TFPR

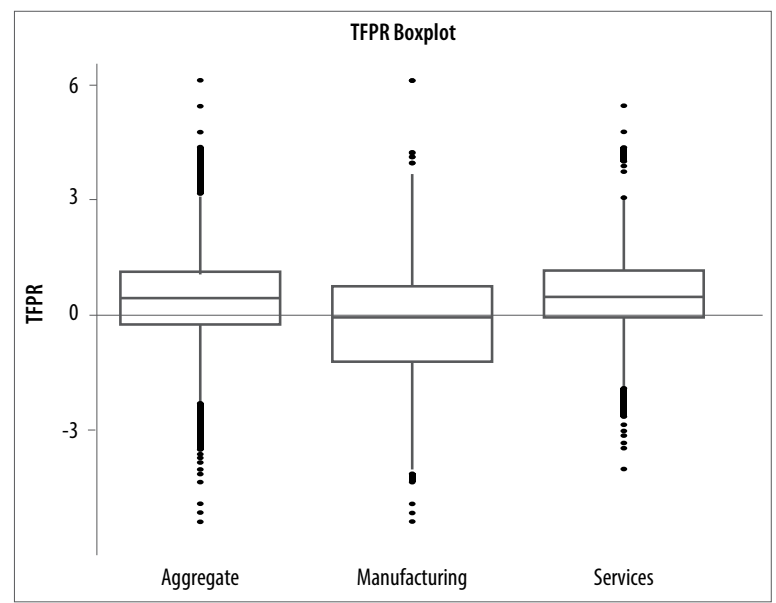

Source: Authors' own elaboration from Census of Industrial Production and Integrated Survey of Services 


\section{Box 2: Indirect measure of allocative efficiency}

The authors show that in the absence of distortions in product prices (e.g., taxes) and factor prices (e.g., labor market regulations, subsidized credit), that is, in the absence of heterogeneous policy treatment of firms in the same industry, optimal input choices and marginal product of capital and labor should equalize across firms. This is true if and only if the production function displays constant returns to scale, consumers are assumed to prefer and love varieties (a la Dixit-Stiglitz), and product mark-ups are constant. Needless to say, the latter are two strong assumptions. In this case, more capital and labor is allocated to firms with high physical TFP (TFPQ). The reallocation of inputs occurs until factor and product markets are in equilibrium (e.g., demand equals supply). By contrast, sizable gaps in marginal products of labor and capital across firms within narrowly defined industries are key signs of misallocation of resources under the identifying assumptions made by the authors.

Hsieh and Klenow also show that when A (TFPQ) and TFPR are jointly log-normally distributed (a specific assumption about the distribution of TFPQ and TFPR and its linear combination), there is a simple closed-form expression for aggregate $\mathrm{TFP}_{1}^{4}$ showing that the variance or dispersion in revenue TFP (TFPR) has a negative impact on aggregate sectoral productivity. In other words, if both TFPQ and TFPR fulfill the statistical assumption used by HK (jointly log-normally distributed), then the extent of misallocation is worse when there is greater dispersion of marginal products.

However, it is worth mentioning that dispersion of physical TFP is not necessarily a measure of misallocation, as this variation can be explained by the randomness of the technological process, which can generate differences in innovation outputs and outcomes across firms, even when optimal input choices in terms of factors of production and R\&D are identical across firms.

$\log T P F_{s}=\frac{1}{(\sigma-1)} \log \left(\sum_{i}^{M_{s}} A_{s i}^{\sigma-1}\right)-\frac{\sigma}{2} \operatorname{variance}\left(\log T F P R_{s i}\right)$

$4 \overline{\log T P F_{S}}=\frac{1}{(\sigma-1)} \log \left(\sum_{i}^{M_{s}} A_{s i}^{\sigma-1}\right)-\frac{\sigma}{2} \operatorname{variance}\left(\log T F P R_{S i}\right)(1)$

Figure 26 shows more dispersion for the manufacturing sector (because of the bigger box) with a lower median and a lot of values concentrated between the $25^{\text {th }}$ and $50^{\text {th }}$ percentile. This suggests the presence of distortions and allocative inefficiency in the manufacturing sector more than in the services sector, which has a smaller box higher up on the vertical axis.

\section{Firms are not growing as they should}

The second indirect way to measure misallocation is to plot the ratio of employment between the bottom 10 percent of firms in terms of productivity and the bottom 50 percent of firms, and compare that to the ratio of employment between the bottom 90 percent and the bottom 50 percent of firms in terms of productivity. The idea is that if labor is 
efficiently allocated across firms within an industry, then employment in the latter should be much higher than employment in the former.

Figure 27 shows this comparison for manufacturing firms, services firms, and firms in the aggregate, using the TFPQ measure of productivity. The larger the bar, the higher the concentration of employment. Figure 27 effectively shows that while employment is concentrated in firms with higher productivity in both the manufacturing and services sector, the difference is much larger in the latter.

Figure 27: Misallocation of labor across sector

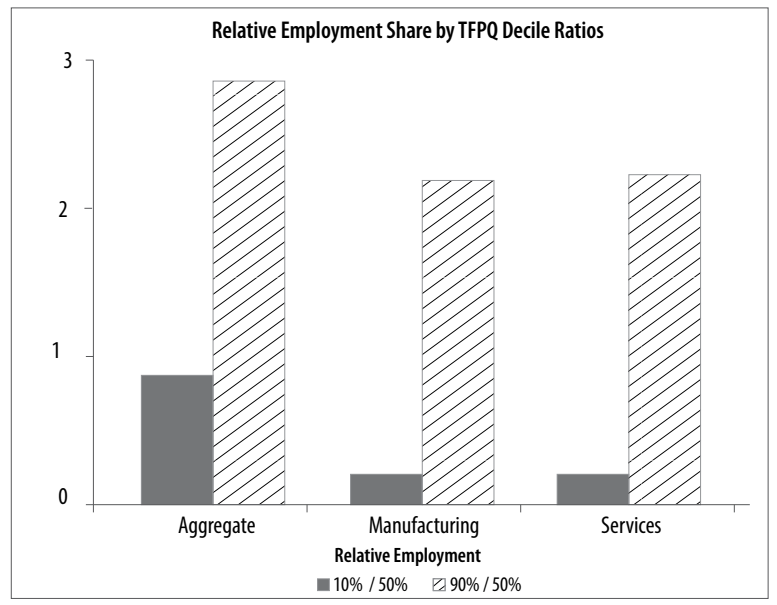

Source: Authors' own elaboration from Census of Industrial Production and Integrated Survey of Services
Figures 28 and 29 show the misallocation of labor by manufacturing and services subsectors. They show that allocative efficiency varies significantly across different subsectors. In manufacturing, there is significant misallocation in metal products, where low productivity firms are larger, or in the leather sector, where some low productivity firms are significantly large. Misallocation in the services sector appears to be less prevalent, although in a significant number of sectors the middle productivity firms are the largest, larger than some highly efficient firms.

\section{Direct measures of allocative efficiency}

The first direct measure of allocative efficiency is the Olley and Pakes (OP) decomposition (Olley and Pakes 1996), which uses the difference between sizemeasured through a firm's employment share or market share in the industry-and productivity to infer the efficiency with which labor or output is allocated across firms, by sector and subsector (Bartelsman, Haltiwanger, Scarpetta 2013). The idea behind this measure is that in a wellfunctioning economy, where there are no policy distortions and no differences in the

Figures 28-29: Misallocation of labor across sectors in the top 10 manufacturing and services sectors

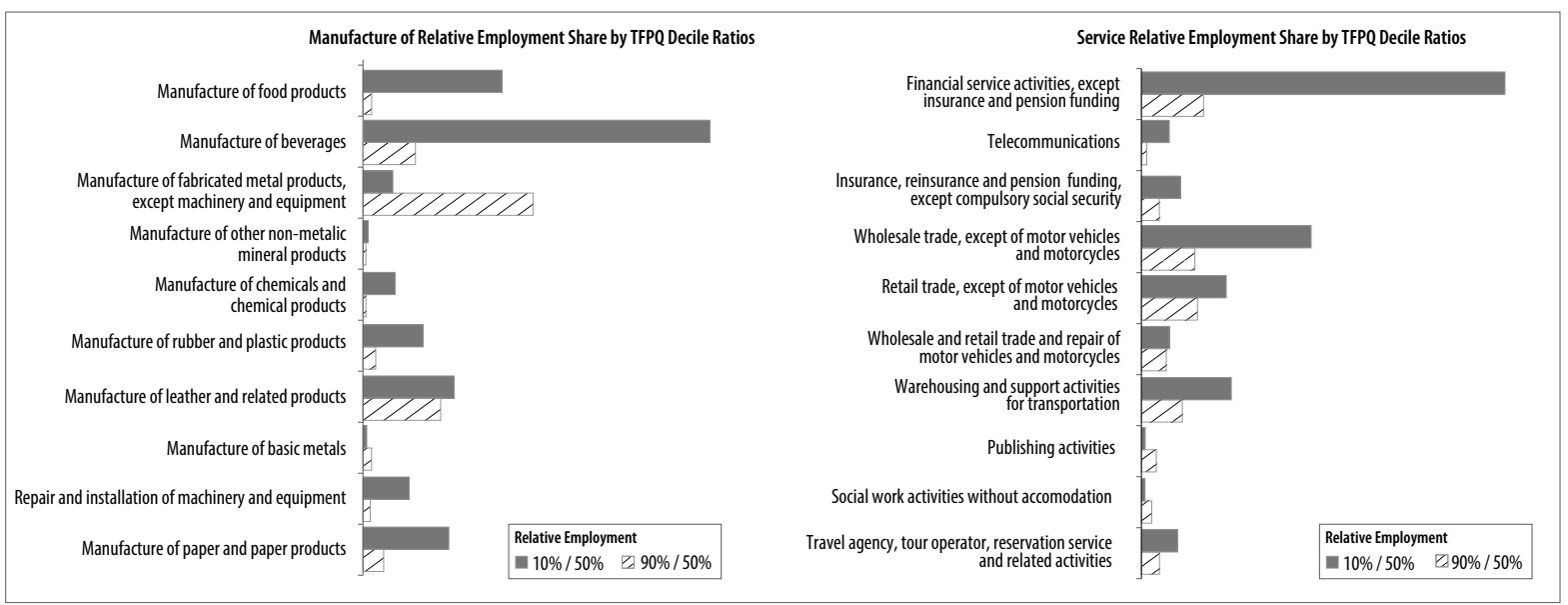

Source: Authors' own elaboration from Census of Industrial Production and Integrated Survey of Services 
way firms are treated by laws and regulations, firms that are more productive are able to hire more labor, use more capital, and earn a larger market share than unproductive firms. ${ }^{5}$

Table 8 shows the Olley-Pakes decomposition in the manufacturing sector, the services sector, and in the aggregate. A high and positive value of the covariance term is associated with high allocative efficiency.

Table 8: Olley-Pakes (OP) decomposition, measuring productivity through TFPQ

\begin{tabular}{|l|c|c|c|c|}
\hline Industry & $\begin{array}{c}\text { Simple } \\
\text { Mean }\end{array}$ & Covariance & $\begin{array}{c}\text { Share of } \\
\text { employment }\end{array}$ & ISIC2 \\
\hline Aggregate & 8.93 & 1.42 & & NA \\
\hline Manufacturing & 8.56 & 1.14 & 43.26 & NA \\
\hline Services & 9.22 & 1.63 & 56.74 & NA \\
\hline
\end{tabular}

Source: Authors' own elaboration from Census of Industrial Production and Integrated Survey of Services

The results in Table 8 show a positive covariance in the aggregate, manufacturing, and services sectors. This suggests that despite the distortions, labor may reallocate to more efficient firms, and in the absence of distortions this positive reallocation could be much higher. Importantly, the covariance for the manufacturing sector is lower than for that of the services sector, indicating that labor reallocates more efficiently in the latter.

Figures 30 and 31 organize manufacturing and services subsectors by their International Standard Industrial Classification of All Economic Activities (ISIC) codes, and plot their OP covariance term to compare them. The figures show that most of the manufacturing and services subsectors display a positive covariance.

Table 9 shows in table format what is displayed in Figures 30 and 31. As before, a high and positive value of the covariance term is associated with high allocative efficiency. The table shows that the highest covariance appears in the most important manufacturing sector, which is food products, while the lowest displays in basic metals. Large misallocation in the services sector is not concentrated in the top-10 sectors. Only a few top 10 services sectors, such as tourism and publishing activities, show negative covariance. Since the values are close to zero, a random allocation of labor across firms is likely.

Figure 30-31: OP Covariance in the manufacturing and services sector

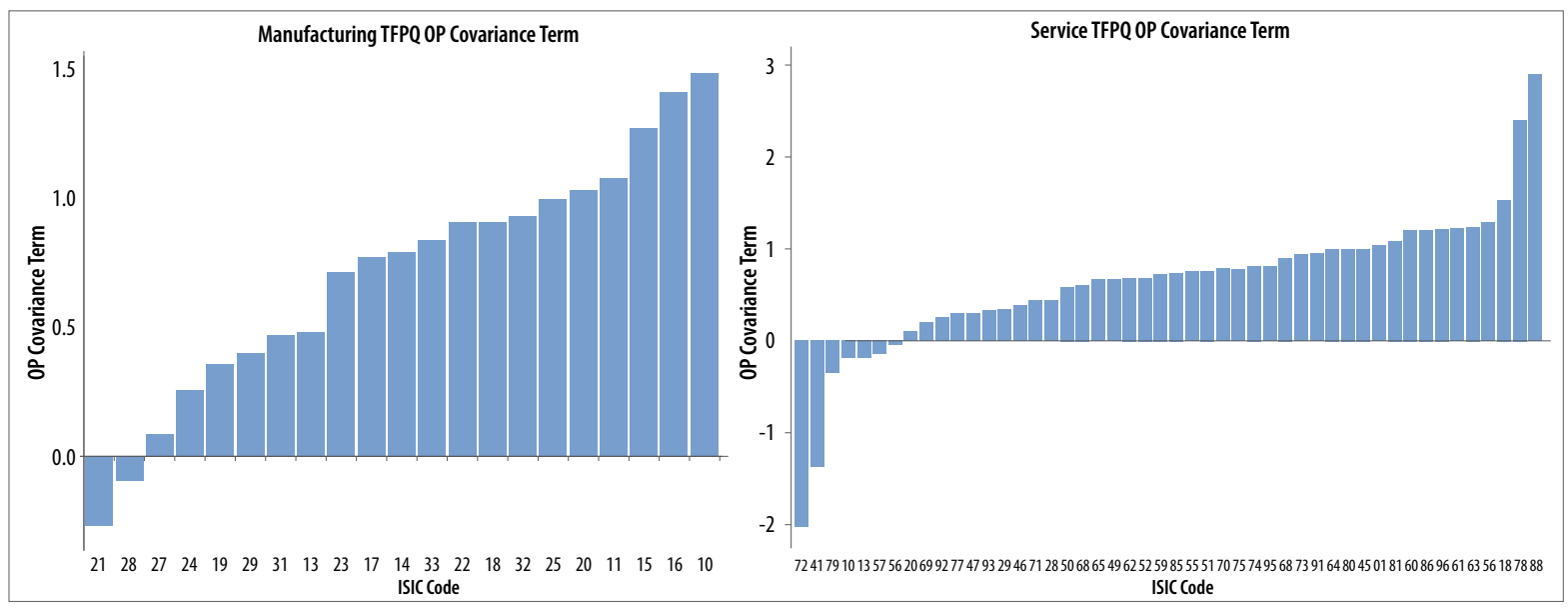

Source: Authors' own elaboration from Census of Industrial Production and Integrated Survey of Services

5 The OP measure decomposes an index of industry-level productivity, defined as the weighted average of firm-level (log) productivity, into a moment of the firm productivity distribution, such as the unweighted firm-level average, and a moment of the joint distribution of productivity and employment share or market share, such as the covariance between both variables. A high and positive value of the covariance term is associated with high allocative efficiency. 
Table 9: OP decomposition (TFPQ, manufacturing top 10 only)

\begin{tabular}{|c|c|c|c|c|}
\hline Industry & Simple Mean & Covariance & $\begin{array}{c}\text { Share of } \\
\text { employment }\end{array}$ & ISIC2 \\
\hline $\begin{array}{l}\text { Manufacture of basic metals } \\
\text { (Manufacturing) }\end{array}$ & 10.35 & 0.26 & 4.23 & 24 \\
\hline $\begin{array}{l}\text { Manufacture of other non-metallic } \\
\text { mineral products (Manufacturing) }\end{array}$ & 8.58 & 0.71 & 2.86 & 23 \\
\hline $\begin{array}{l}\text { Manufacture of paper and paper } \\
\text { products (Manufacturing) }\end{array}$ & 8.78 & 0.77 & 3.24 & 17 \\
\hline $\begin{array}{l}\text { Repair and installation of machinery } \\
\text { and equipment (Manufacturing) }\end{array}$ & 9.07 & 0.84 & 0.94 & 33 \\
\hline $\begin{array}{l}\text { Manufacture of rubber and plastics } \\
\text { products (Manufacturing) }\end{array}$ & 9.08 & 0.91 & 4.82 & 22 \\
\hline $\begin{array}{l}\text { Manufacture of fabricated metal } \\
\text { products, except machinery and } \\
\text { equipment (Manufacturing) }\end{array}$ & 9.15 & 1 & 2.92 & 25 \\
\hline $\begin{array}{l}\text { Manufacture of chemicals and } \\
\text { chemical products (Manufacturing) }\end{array}$ & 9.39 & 1.03 & 3.63 & 20 \\
\hline $\begin{array}{l}\text { Manufacture of beverages } \\
\text { (Manufacturing) }\end{array}$ & 8.82 & 1.08 & 3.66 & 11 \\
\hline $\begin{array}{l}\text { Manufacture of leather and related } \\
\text { products (Manufacturing) }\end{array}$ & 9.69 & 1.27 & 3.24 & 15 \\
\hline $\begin{array}{l}\text { Manufacture of food products } \\
\text { (Manufacturing) }\end{array}$ & 8.44 & 1.48 & 42.76 & 10 \\
\hline \multicolumn{5}{|c|}{ Services (Top 10 only) } \\
\hline $\begin{array}{l}\text { Travel agency, tour operator, } \\
\text { reservation service and related } \\
\text { activities (Services) }\end{array}$ & 9.74 & -0.35 & 2.77 & 79 \\
\hline Publishing activities (Services) & 10.11 & -0.05 & 0.67 & 58 \\
\hline $\begin{array}{l}\text { Retail trade, except of motor vehicles } \\
\text { and motorcycles (Services) }\end{array}$ & 9.25 & 0.3 & 5.91 & 47 \\
\hline $\begin{array}{l}\text { Wholesale trade, except of motor } \\
\text { vehicles and motorcycles (Services) }\end{array}$ & 9.49 & 0.38 & 6.72 & 46 \\
\hline $\begin{array}{l}\text { Insurance, reinsurance and pension } \\
\text { funding, except compulsory social } \\
\text { security (Services) }\end{array}$ & 10.97 & 0.67 & 1.3 & 65 \\
\hline $\begin{array}{l}\text { Warehousing and support activities for } \\
\text { transportation (Services) }\end{array}$ & 10.05 & 0.68 & 1.78 & 52 \\
\hline $\begin{array}{l}\text { Financial service activities, except } \\
\text { insurance and pension funding } \\
\text { (Services) }\end{array}$ & 10.04 & 1 & 3.46 & 64 \\
\hline $\begin{array}{l}\text { Wholesale and retail trade and repair } \\
\text { of motor vehicles and motorcycles } \\
\text { (Services) }\end{array}$ & 9.23 & 1 & 2.37 & 45 \\
\hline Telecommunications (Services) & 10.53 & 1.23 & 2.24 & 61 \\
\hline $\begin{array}{l}\text { Social work activities without } \\
\text { accommodation (Services) }\end{array}$ & 10.19 & 2.89 & 1.01 & 88 \\
\hline
\end{tabular}

Source: Authors' own elaboration from Census of Industrial Production and Integrated Survey of Services 


\section{Distortions and misallocation}

The second direct measure of allocative efficiency involves the calculation of firm distortions and the productivity gains a country can obtain by removing those distortions. Cirera et al. (2015) directly estimate these distortions, and Table 10 shows the average value of distortions in factor prices and product prices, both in an absolute sense and weighted by employment. The higher the number, the higher the distortion. Table 10 shows that capital distortions are higher than output distortions. Capital distortions are higher in the services sector than manufacturing. However, the reverse occurs in terms of output distortions, which are almost negligible in the services sector.

\section{There are large efficiency gains from removing distortions}

Once the distortions have been calculated, one can conduct two counterfactual exercises: (i) what would have been the size of a firm under the absence of distortions; and (ii) how would this affect the allocation of labor and capital across firms and sectors?

Estimations by Cirera et al. (2015) show that efficiency gains from equalizing marginal products to the US are between 163 percent and 195 percent for the manufacturing sector and between 143 percent and 163 percent for the services sector (assuming a product elasticity of substitution of 3 and 5). ${ }^{6}$

These are very large numbers and suggest that understanding the nature of these distortions and effectively removing them is likely to have very large returns. Identifying the nature of these distortions is not an easy task, however, since different regulations and market failures affect the allocation of factors of production. Cirera et al. (2015) suggest that the relative costs from corruption and lack of access to finance is likely to explain a significant part of these distortions, although the data doesn't allow the authors to empirically confront this theory.

\section{Key takeaways from the overall Kenyan productivity analysis}

Before moving into the final section, which presents the main conclusions and policy recommendations, we would like to summarize the key takeaways from the overall productivity analysis for Kenya. The following bullet points present the main conclusions for the cross-sectors and withinsector analysis.

Table 10: Capital and output distortion averages

\begin{tabular}{|l|c|c|c|c|}
\hline & $\begin{array}{c}\text { Ave. capital } \\
\text { distortion }\end{array}$ & $\begin{array}{c}\text { Ave. output } \\
\text { distortion }\end{array}$ & $\begin{array}{c}\text { Weighted ave. } \\
\text { capital } \\
\text { distortion* }\end{array}$ & $\begin{array}{c}\text { Weighted ave. } \\
\text { output } \\
\text { distortion* }\end{array}$ \\
\hline Aggregate & 1.79 & 0.05 & 0.44 & -0.35 \\
\hline Manufacturing & 1.52 & 0.27 & 1.54 & 0.37 \\
\hline Services & 1.90 & -0.03 & -0.39 & -0.90 \\
\hline
\end{tabular}

Source: Cirera et al. (2015)

*Weighted by Employment

\footnotetext{
6 This is an assumption that needs to be made in order to calculate the efficiency gains. In the analytical framework used by HK, there is a constant elasticity of substitution (CES) between goods, which comes from consumers' preferences, and it's reflected in the demand for each good. The CES assumption for consumers' preferences means that the utility function has a constant percentage change in goods proportions (e.g., $x$ and $y$ ) due to a percentage change in marginal rate of substitution.
} 


\section{Cross-sector analysis:}

a. Overall, labor efficiency gains in Kenya seem to be most likely obtained through technological change, including innovation and technology adoption, rather than through the accumulation of capital.

b. Services firms appear to be more productive than manufacturing firms.

c. Misallocation of labor is observed both in the services and manufacturing sectors, although it is less prevalent in the services sector.

d. Allocative efficiency varies significantly across sub-sectors, both within the services and manufacturing sectors.

e. There are very large efficiency gains from removing policy distortions both in the services and manufacturing sectors.

\section{Within-sector analysis:}

a. There is a lot of dispersion in firm productivity-performance within the services and manufacturing sectors. This dispersion may be a consequence of several factors, including: (i) policy distortions; (ii) different product markups due to differences in market power; (iii) different intermediate inputs/factors of production costs due to differences in firms' bargaining power; and/or (iv) different adjustments costs.

b. Technological gaps are larger than labor efficiency gaps.

c. There is a lot of heterogeneity in firm productivity-performance across different types of firms in the manufacturing industry:

- Size: (i) Small firms tend to produce more value-added per worker than large firms but differences in labor productivity across different size groups are not significant; (ii)
Large firms tend to display a better performance than small firms in terms of technical efficiency, which may be explained by the fact that large firms are more capable of overcoming the large fixed costs of innovating.

- Age: (i) Mature firms are more productive in terms of labor and technical efficiency than young firms in the manufacturing sector; (ii) however, revenue TFP is larger for young firms, suggesting that distortions have a larger and more favorable impact on these firms than on larger firms.

- Export-status: (i) Exporters display a better productivity-performance than non-exporter firms; (ii) The productivity gap between exporters and non-exporters is larger when both groups are compared according to their technical efficiency instead of labor efficiency, suggesting that investments in technological change (e.g., innovation and technology adoption) can be more effective than investments in capital to help firms achieve the minimum level of efficiency required to overcome the fixed costs of exporting; (iii) interestingly, there are no significant differences between exporters and non-exporters when measuring productivity through TFPR, suggesting that the passthrough of efficiency gains to final prices obtained by exporting firms, probably ex-ante to enter into international markets, is high; (iv) Alternatively, the lack of differences between both TFPR distributions may reflect the fact that non-exporting firms face relatively more distortions than exporting firms. 


\section{IMPLICATIONS FOR POLICY}

T his note has provided a detailed description of firm-level productivity in the manufacturing and services sectors in Kenya. The results of the analysis portrays a picture of firm dynamics in Kenya that is significantly dysfunctional and results in the fact that there are significant market distortions that make firms in Kenya coexist at very different productivity levels, even within very narrowly defined industries. The dispersion of revenue TFP may capture the presence of economic distortions both in factor and product markets and/or heterogeneity of mark-ups across firms. In addition, the dispersion in physical TFP may reflect the random nature of the innovation process and/or the heterogeneity in firms' attributes and capabilities, suggesting that economic policies geared to foster productivity at the aggregate level should depart from the standard assumption of a representative firm.

More importantly, the results put policies that enhance productivity and remove distortions at the center stage of the economic policy agenda in Kenya. The observed misallocation, reflected for instance in the negative covariance between productivity and employment, is likely to result in lower aggregate productivity, especially in the manufacturing sectors where this misallocation is more prevalent and significantly larger than in some other peer countries in Africa. Some estimates calculate the potential productivity increase from removing these distortions and achieving an efficient allocation of labor and capital across firms as more than 160 percent (Cirera, Fattal-Jaef, Maemir 2015). This could have a very large impact on economic growth, and more importantly, on the creation of high quality jobs that the country needs to absorb a rapidly increasing labor force.

The findings in this report also have important implications for the design and implementation of existing policies. First, policies oriented to promote economic growth should concentrate on removing distortions and leveling the playing field for all types of firms. Although there data limitations do not allow us to identify the type of distortions that explain the observed misallocation, there is evidence that entrepreneurs in Kenya continue to face burdensome institutional and regulatory barriers that not only affect their ability to cover the fixed costs of entering into the domestic market, but also their capacity to generate post-entry growth. This is a common problem in several developing countries. These barriers affect incumbents' ability to increase profits, create new jobs, and supply high value-added exports. There is a need to improve the business environment across the board and to ensure a non-discriminatory implementation of business regulations and administrative requirements across all firms.

Second, policy targeting should take into consideration the large heterogeneity of attributes and performance across Kenyan firms. Laggard firms in Kenya are very far away 
from the productivity frontier and therefore, generic policies, targeting very different firms with the same instrument, may fail to achieve the expected objectives. By contrast, tailoring the interventions to the specific needs of a particular group of firms can be more effective in enhancing aggregate efficiency. For example, export promotion policies that aimed at reducing the large fixed costs of entering into international markets may fail to boost aggregate exports if low productivity firms are targeted, given the fact that the distribution of efficiency is highly dispersed.

Third, one implication of the analysis is the fact that policies aimed at changing the behavior of macroeconomic variables should rely on granular diagnostics that explore patterns of economic activity at the firm-level. A clear example is the need to examine firms' behavior to rationalize the relatively lackluster performance of the Kenyan manufacturing sector. A significant number of aggregate studies have documented a continuous loss of competitiveness of Kenyan firms, both in regional and international markets, coupled with the declining role of the manufacturing sector in the overall economy. The analysis presented in this microeconomic diagnostic provides foundations to explain the observed aggregate results.

Overall, the findings highlight the importance of locating productivity at the center of the competitiveness and economic growth agenda as a key instrument for employment creation and poverty reduction. 


\section{REFERENCES}

Aghion,Philippe, Nick Bloom, Richard Blundell, Rachel Griffith, and Peter Howitt. (2005). "Competition and Innovation: An Inverted-U Relationship." The Quarterly Journal of Economics 120 (2): 701-728.

Alfaro, Laura, Andrew Charlton, and Fabio Kanczuk. (2008). "Firm-Size Distribution and Cross-Country Income Differences." National Bureau of Economic Research Working Paper 14060.

Asker, John, Allan Collard-Wexler, and Jan De Loecker. (2014). "Dynamic Inputs and Resource (Mis) Allocation. "The Journal of Political Economy 122 (5).

Bartelsman, Eric, John Haltiwanger, and Stefano Scarpetta. (2013). "Cross-country Differences in Productivity: The role of Allocation and Selection." American Economic Review 103 (1): 305-334.

Christiaensen, Luc, Lionel Demery, and Jesper Kuhl. (2011). "The (Evolving) Role of Agriculture in Poverty Reduction-An Empirical Perspective." Journal of Development Economics 96 (2): 239-54.

Christiaensen, Luc, Ruchira Bhattamishra, Lei Pan, and Sangui Wang. (2009). "Pathways Out of Poverty in Lagging Regions: Evidence from Rural Western China." World Bank, Washington, DC.

Cirera, Xavier (2015). "Catching Up to the Technological Frontier?," World Bank Other Operational Studies 21684, The World Bank.

Cirera, Xavier, Roberto N. Fattal-Jaef, and Hibret B. Maemir. (2015). "Taxing the good? Distortions, Misallocation, and Productivity in Sub-Saharan Africa." The World Bank, Mimeo.

Dang, Hai-Anh, and Peter Lanjouw. (2012). "Measuring Poverty Dynamics and Labor Transitions with Synthetic Panels Based on Cross-Sections." World Bank Policy Research Working Paper Series \#6504.

De Loecker, J. (2011). "Product Differentiation, Multi-Product Firms and Estimating the Impact of Trade Liberalization on Productivity", Econometrica, Vol. 79, No. 5 (September), 1407-1451.

Easterly, William, and Ross Levine. (2001). "What have we learned from a decade of empirical research on growth? It's Not Factor Accumulation: Stylized Facts and Growth Models." World Bank Econ Review15 (2): 177-219.

Haltiwanger, John. (2007). "Measuring and Analyzing Aggregate Fluctuations: The Importance of Building from Microeconomic Evidence." Federal Reserve Bank of St. Louis Review 79 (3): 55-78.

Hsieh, Chang-Tai, and Peter Klenow. (2009). "Misallocation and Manufacturing TFP in China and India." Quarterly Journal of Economics 124 (4): 1403-48.

Krugman, Paul. (1994). "The Age of Diminished Expectations." Cambridge: MIT Press.

Melitz, Marc. (2003). "The Impact of Trade on Intra-Industry Reallocations and Aggregate Industry Productivity. " Econometrica, Econometric Society 71 (6): 1695-1725, November.

Midrigan, Virgiliu, and Daniel Yi Xu. (2010). "Finance and Misallocation: Evidence from Plant-level Data." National Bureau of Economic Research Working Paper 15647.

Olley, G. Steven, and Ariel Pakes. (1996). "The Dynamics of Productivity in the Telecommunications Equipment Industry." Econometrica 64 (6): 1263-97. 
Pages, Carmen. (2010). "The Age of Productivity: Transforming Economies from the Bottom Up." InterAmerican Development Bank. Washington, DC: Palgrave Macmillan.

Restuccia, Diego, and Richard Rogerson. (2008). "Policy Distortions and Aggregate Productivity with Heterogeneous Establishments." Review of Economic Dynamics 11 (4): 707-20.

Syverson, Chad. (2011). "What Determines Productivity?"Journal of Economic Literature 49:2, 326-365.

Vries, Gaaitzen de, Marcel Timmer, and Klass de Vries. (2013). "Structural Transformation in Africa: Static Gains, Dynamic Losses." GGDC Research Memorandum 136. 


\section{Box A1: Productivity variables used in the analysis}

\section{TFP estimated}

Firm-level productivity is calculated using a Cobb-Douglas production function $A_{i}=\frac{Y_{i}}{K_{i}^{\alpha} L_{i}^{1-\alpha}}$, where $A_{i}$ is productivity of firm i, $Y_{i}$ is value added of firm $i, L_{i}$ and $K_{i}$ are the labor and capital inputs, respectively.

\section{TFPR - revenue productivity}

- Empirical implementation. The implicit distortions faced by each firm can be inferred from firm's profit maximization conditions.

- Factor distortions. The factor (capital-labor) distortions can be recovered from the first-order conditions $\tau_{k i}=\frac{\alpha_{s}}{1-\alpha_{s}} \frac{w L_{i}}{R K_{i}}-1$, suggesting that a firm faces a higher capital-labor distortion if ratio of labor compensation to the stock of capital is larger than what is warranted by the industry elasticity of output with respect to factors of production. The factor shares $\left(\alpha_{s}\right)$ are taken from NBER dataset, which are based on industry-level factor share in the U.S.

- Output distortion. Similarly, the output distortion can be recovered from the optimality condition as $\tau_{y i}=1-\frac{\sigma}{\sigma-1} \frac{w L_{i}}{\left(1-\alpha_{s}\right) P_{i} Y_{i}}$, implying that a firm faces a higher output distortion if the labor compensation is low compared to what is implied by industry elasticity of output with respect to labor. The output distortion does not distort the optimal factor input combination as it affects the marginal products of both inputs proportionally.

$T F P R_{i}=P_{i} A_{i} \propto \frac{\left(1+\tau_{k i}\right)^{\alpha}}{\left(1-\tau_{y i}\right)}$. In a frictionless environment, where all firms face the same level of distortion, that is, $\tau_{k i}=\overline{\tau_{k}}$ and $\tau_{y i}=\overline{\tau_{y}}$, TFPR should be equalized across firms. Therefore, TFPR dispersion across firms can be interpreted as a misallocation of resources.

\section{TFPQ - physical productivity}

To calculate firm-level physical productivity, we need data on physical output $Y_{i}$. Unfortunately, such information is not available in our datasets. The datasets, however, report the value of production $P_{i} Y_{i}$.

One way to obtain the physical output is to deflate the values by the industry price deflator (since firm level prices are not available), that is, $\frac{P_{i} Y_{i}}{P}$, where $\mathrm{P}$ is the industry price index. While this is a plausible approach in homogenous goods industries, firm-level prices may vary relative to the industry price index in differentiated product industries. If so, this approach yields a contaminated measure of productivity, since within-industry price differences are lumped into productivity measures. This measure is often referred as revenue total factor productivity (TFPR).

Following Hsieh \& Klenow (2009), physical productivity can be inferred for each firm by imposing an assumption on the demand structure of firms, that is, $A_{i}=\frac{Y_{i}}{K_{i}^{\alpha} L_{i}^{1-\alpha}} \propto \frac{\left(P_{i} Y_{i}\right)^{\frac{\sigma}{\sigma-1}}}{K_{i}^{\alpha} L_{i}^{1-\alpha}}$, where $\sigma$ is the elasticity of substitutions between products within industries. 


World Bank Group

Delta Center

Menengai Road, Upper Hill

P. O. Box 30577 - 00100

Nairobi, Kenya

Telephone: +254202936000 